\title{
A EXTENSÃO DO PRAZO DE VALIDADE DE PATENTES COMO UMA DAS CAUSAS DA JUDICIALIZAÇÃO DE MEDICAMENTOS NO BRASIL
}

\author{
THE EXTENSION OF THE VALIDITY PERIOD OF PATENTS AS ONE OF \\ THE CAUSES OF THE JUDICIALIZATION OF MEDICINES IN BRAZIL
}

\author{
LA EXTENSIÓN DEL PLAZO DE VALIDEZ DEL PATENTES COMO UNA \\ DE LAS CAUSAS DE LA JUDICIALIZACIÓN DE MEDICAMENTOS EN \\ BRASIL
}

\author{
Rafaella Dias Gonçalves ${ }^{1}$ \\ https://orcid.org/0000-0001-7288-3904 \\ http://lattes.cnpq.br/2261521959271509
}

RECEBIBO 29/01/2019

APROVADO 30/01/2019

PUBLICADO 04/01/2019

Editor Responsável: Carla Caldas

Método de Avaliação: Double Blind Review

E-ISSN: 2316-8080

DOI: 10.16928

\section{RESUMO}

À revelia da disponibilidade de recursos materiais e humanos sob a averiguação prévia orçamentária, o poder judiciário, de há muito no Brasil, vem arrogando uma legitimidade constitucional para o controle e intervenção nas políticas públicas nos casos em que considera o governo omisso à concretização da saúde para o fornecimento de medicamentos não distribuídos por meio do SUS. Desse modo, o fenômeno da judicialização de medicamentos, cada vez mais fortalecido na interpretação da fundamentalidade da saúde por efeito imediato, se opera em números já contundentes de ações judiciais no país, camuflando um êxito no domínio da proteção à saúde. Tal, reflete a ineficiência de políticas públicas confiadas ao Poder Legislativo e Executivo brasileiro, o que pode ser observado com mais clareza quando na análise interdisciplinar do fenômeno da judicialização com o estudo de outros subsistemas. Dentre este feixe de subsistemas, objetiva-se, pois, analisar que embora o monopólio temporário de patentes

\footnotetext{
${ }^{1}$ Mestre em Direito Constitucional (2018) pela Universidade de Coimbra (UC), Portugal. Investigadora em Direito Civil (2018) na Universidade de Sevilla (US), Espanha. Investigadora visitante no Mestrado em Análises Econômicas e Políticas Públicas (2017/2018) pela Universidade de Salamanca (USAL), Espanha. Pós-Graduanda em Direito Público, Direito do Trabalho e Direito Previdenciário (2014) pela Universidade Estácio de Sá (FIC) - Ceará - Brasil. Advogada inscrita na Ordem dos Advogados do Brasil (2011). Bacharela em Direito (2010) pela Universidade Estácio de Sá (FIC), Brasil | rafaelladias.adv@gmail.com.
} 
tenha guarida constitucional e a propriedade intelectual constitua incentivo ao investimento e inovação de medicamentos, a extensão do prazo de validade de patentes, consagrada no ordenamento jurídico brasileiro, impede a entrada de genéricos no mercado de medicamentos que já deveriam estar sob o domínio público, contribui com o avolumar jurisprudencial por força da então judicialização de medicamentos: um entrave para o poder judiciário brasileiro, um desequilíbrio nas contas públicas, na medida em que se reveste de modelo paliativo que desvia forçosamente verbas não negligenciáveis universalizadas na dotação orçamentária para atender imposições concretas.

PALAVRAS-CHAVE: Judicialização de Medicamentos. Propriedade Intelectual. Extensão de patentes farmacêuticas.

\begin{abstract}
In spite of the availability of material and human resources under previous budgetary research, the judiciary, long in Brazil, has arrogated a constitutional legitimacy to control and intervene in public policies in cases in which it considers the government to fail to achieve health for the supply of medicines not distributed through SUS. In this way, the phenomenon of the judicialization of medicines, increasingly strengthened in the interpretation of the fundamentality of health by immediate effect, operates in already strong numbers of lawsuits in the country, camouflaging a success in the field of health protection. This reflects the inefficiency of public policies entrusted to the Brazilian Legislative and Executive Power, which can be observed more clearly when in the interdisciplinary analysis of the phenomenon of judicialization with the study of other subsystems. The aim of this subsystem is to analyze that although the temporary monopoly of patents has a constitutional guarantee and intellectual property constitutes an incentive for the investment and innovation of drugs, the extension of the period of validity of patents, enshrined in the Brazilian legal system, prevents the entry of generics in the market of medicines that should already be in the public domain, contributes to the increase of jurisprudence due to the then judicialization of medicines: an obstacle to the Brazilian judiciary, an imbalance in public accounts, to the extent that is a palliative model that forcibly diverts non-negligible universalized funds from the budget to meet specific demands.
\end{abstract}

KEYWORDS: Judicialization of Medications. Intellectual property. Extension of pharmaceutical patents.

\title{
RESUMEN
}

En cuanto a la disponibilidad de recursos materiales y humanos bajo la investigación previa presupuestaria, el poder judicial, desde hace mucho en Brasil, viene arrogando una 
legitimidad constitucional para el control e intervención en las políticas públicas en los casos en que considera al gobierno omiso a la concreción de la salud para el suministro de medicamentos no distribuidos por medio del SUS. De este modo, el fenómeno de la judicialización de medicamentos, cada vez más fortalecido en la interpretación de la fundamentalidad de la salud por efecto inmediato, se opera en números ya contundentes de acciones judiciales en el país, camuflando un éxito en el dominio de la protección a la salud. Tal, refleja la ineficiencia de políticas públicas confiadas al Poder Legislativo y Ejecutivo brasileño, lo que puede ser observado con más claridad cuando en el análisis interdisciplinario del fenómeno de la judicialización con el estudio de otros subsistemas. En el presente trabajo se analizan los resultados obtenidos en el análisis de los resultados obtenidos en el análisis de los resultados obtenidos, , impide la entrada de genéricos en el mercado de medicamentos que ya deberían estar bajo el dominio público, contribuye con el avolumar jurisprudencial en virtud de la entonces judicialización de medicamentos: un obstáculo para el poder judicial brasileño, un desequilibrio en las cuentas públicas, en la medida en que se reviste de modelo paliativo que desvía forzosamente fondos no despreciables universalizados en la dotación presupuestaria para atender imposiciones concretas.

PALABRAS CLAVE: Judicialización de Medicamentos. Propiedad intelectual. Extensión de patentes farmacéuticas. 


\section{INTRODUÇÃO}

A realidade brasileira de acesso à medicamentos não listados pelo SUS, os quais são comumentes perseguidos através de ações judiciais no desiderato do direito fundamental à saúde, tem, há muito, estado no centro de conflitos sociais que se manifestam num mundo marcado por colisões de valores de direitos humanos fundamentais.

Uma das causas está na problemática da extensão do prazo de validade de patentes de medicamentos de referência diante de medicamentos genéricos, onde defrontam-se duas dimensões essenciais do direito à saúde. Uma que se destaca pela inovação e desenvolvimento de medicamentos pioneiros, cujo objetivo é a descoberta de entidades químicas para suprir as carências e emergências sanitárias a nível global, com o monopólio temporário de patentes, ao passo que a outra privilegia a acessibilidade a medicamentos mais baratos, sobretudo a países em desenvolvimento que possuem pouca ou nenhuma estrutura de investigação tecnológica farmacêutica.

Com a adoção da Lei de propriedade industrial 9.276/1996 brasileira que veio na sequência da incorporação do Acordo TRIPS, o monopólio desmesurado, fruto da extensão do prazo de validade de patentes contida nessa lei, alimenta a leniência da administração pública que por sua vez vem incorrendo em atrasos excessivos na análise de concessão das patentes farmacêutica, resultando no conhecido fenômeno do backlog de patentes. O backlog de patentes acrescido à extensão do prazo contido no regime de propriedade industrial brasileiro são fatores que estão sobrecarregando os cofres públicos com o pagamento vultoso de medicamentos que já deveriam estar sob o domínio público.

Consequentemente, o alto custo de alguns medicamentos, sobretudo para tratamentos oncológicos não fornecidos pelo SUS, contribui para a inacessibilidade de seu consumo pela população, o que acaba por ser motor propulsor ao fenômeno da judicialização de medicamentos no Brasil. Ou seja, a jurisprudência dos tribunais superiores, máxime o Supremo Tribunal Federal (STF), tem trabalhado, diga-se de 
passagem, com uma margem de grande proatividade em resposta a patologias verificadas no próprio setor da saúde enquanto reflexo da ineficiência legiferante e de subsistemas, no que toca o acesso a medicamentos.

Dentre este feixe de subsistemas, objetiva-se, pois, analisar que embora o monopólio temporário de patentes tenha guarida constitucional e a propriedade intelectual constitua incentivo ao investimento e inovação, a perenização legal de patentes consagrada no ordenamento jurídico brasileiro impede a entrada de genéricos no mercado de medicamentos que já deveriam estar sob o domínio público, contribui com o avolumar jurisprudencial por força da então judicialização de medicamentos: um entrave para o poder judiciário brasileiro, um desequilíbrio nas contas públicas, na medida em que se reveste de modelo paliativo que desvia forçosamente verbas não negligenciáveis para atender imposições concretas.

\section{JUDICIALIZAÇÃO DE MEDICAMENTOS NO BRASIL}

O termo "judicialização" vem estendendo sua capacidade normativa, na medida em que o judiciário se mune de meios e modos para o exercício de intervenção em questões de larga repercussão política ou social que não estão sendo decididas pelas instâncias políticas tradicionais: o Congresso Nacional e o Poder Executivo. "Examina-se o diagnóstico sobre os inéditos papeis exercidos pelo Judiciário nas sociedades contemporâneas. Sublinhou-se, então, o amplo consenso quanto à configuração de um novo panorama mundial, caracterizado pela incapacidade de o Executivo e o Legislativo fornecerem respostas efetivas à exploração das demandas sociais por justiça”. (VIANNA, CARVALHO, MELO, BURGOS, 1999, p. 149).

Um aspecto que fortalece o fenômeno "do gigantismo do Poder Judiciário" ${ }^{2}$, no levante ao direito à saúde, é a aplicabilidade por parte dos tribunais do art. $6^{\circ}$, conferindo também o efeito imediato à saúde, enquanto direito fundamental na interpretação conjunta do Art. 196, todos da Constituição Federal Brasileira ${ }^{3}$. Diferentemente do que ocorre no

\footnotetext{
${ }^{2}$ Expressão do autor JURGEN HABERMANS, que sustenta a tese procedimentalista e critica veementemente a invasão da política e da sociedade pelo Direito, surgidas no pós-guerra. Para maiores elucubrações, Cf. HABERMAS, Jürgen. Direito e Democracia - entre facticidade e validade. vol. I. Rio de Janeiro: Tempo Brasileiro, 2003, p. 297-298.

${ }^{3}$ Os direitos sociais foram recepcionados na Constituição da República Federativa do Brasil (CFB) de 1988, mais precisamente no Título II (Dos Direitos e Garantias Fundamentais), especificados no art. $6^{\circ}$ (Dos
} 
direito português ${ }^{4}$, não é novidade que o Brasil adotou, em posição majoritária, a tese da "indivisibilidade" de regime dos direitos fundamentais, sendo essa posição sustentada pelos tribunais, como pode ser observado através de uma gama de arestos, especialmente do $\mathrm{STF}^{5}$. Para essa quase unânime corrente, todos os direitos fundamentais, incluindo os direitos sociais, possuem a mesma relevância jurídica, pois todos foram recepcionados pela Constituição, se baseiam na dignidade da pessoa humana e estão subordinados ao mesmo regime jurídico, previsto no $\left(\operatorname{art} .5^{\circ}, \S 1^{\circ}\right)^{6}$ da $\mathrm{CFB}$, que lhes confere, sem exceção, a aplicabilidade imediata ${ }^{7}$.

Todavia, essa posição, que tem como defensores, entre tantos outros, SARLET $(2008)^{8}$ e MORAES (2017) ${ }^{9}$, tem vindo ultimamente a ser mais moderada, através de um recuo de alguns dos seus expoentes, que nos convidam a refletir sobre a vigência social do direito à saúde na problemática dos “custos do direito" traduzido pela conhecida noção

Direitos Sociais), ainda que não de forma exaustiva, com a seguinte redação: "[s]ão direitos sociais a educação, a saúde, a alimentação, o trabalho, a moradia, o transporte, o lazer, a segurança, a previdência social, a proteção à maternidade e à infância, a assistência aos desamparados, na forma desta Constituição". Cf BRASIL, Constituição da República Brasileira de 1988. Disponível em http://www.planalto.gov.br/ccivil 03/constituicao/constituicaocompilado.htm Acesso em 02 de abril de 2018.

${ }^{4}$ Para a doutrina majoritária portuguesa, os direitos sociais são direitos de natureza positiva, sem densidade suficientemente bastante para alcançar o nível de determinabilidade necessária para fruírem do regime dos direitos, liberdades e garantias. Contundo, não se descarta o reconhecimento à força jurídica em referência imediata à dignidade da pessoa humana. Cf. CANOTILHO, Gomes J.J, Para uma Revisão da Dogmática da Jusfundamentalidade, in "Estudos em Homenagem a Antonio Barbosa de Melo", Coimbra, Almedina, 2013, p. 533-554, em especial, p. 539-541. Há também a corrente minoritária da doutrina portuguesa da dualidade de regimes constitucionais dos direitos fundamentais, em que seu lídimo defensor é NoVAIS, Jorge Reis, Direitos Sociais - Teoria Jurídica dos Direitos Sociais Enquanto Direitos Fundamentais, Coimbra, Wolters Kluwe/Coimbra Editora, 2010, p. 36-86 e 251-331.

${ }^{5}$ STF, dentre muitos, Cf. RE 668.722 AgR, rel. min. Dias Toffoli, j. 27-8-2013, $1^{\text {a }}$ T, DJE de 25-10-2013; AI 734.487 AgR, rel. min. Ellen Gracie, j. 3-8-2010, 2a T, DJE de 20-8-2010.

6 "Art. $5^{\circ}$ Todos são iguais perante a lei, sem distinção de qualquer natureza, garantindo-se aos brasileiros e aos estrangeiros residentes no País a inviolabilidade do direito à vida, à liberdade, à igualdade, à segurança e à propriedade, nos termos seguintes: $[. ..] \S 1^{\mathrm{a}}$ As normas definidoras dos direitos e garantias fundamentais têm aplicação imediata". Vide supra nota 82.

${ }^{7}$ Neste plano, a experiência sul-africana colocou sob a alçada do Tribunal Constitucional a reivindicação dos direitos de subsistência dos excluídos, como grupo, o que foi possível porque a Constituição sulafricana consagra os direitos sociais e dá aos juízes, aí, poder idêntico aos que lhes confere quanto à proteção dos direitos, liberdades e garantias. Cf. a propósito, BILCHITZ, David - Poverty and Fundamental Rights, New York, 2007, pág 133 e segs.

${ }^{8}$ Para maiores desenvolvimentos sobre o tema, cf. SARLET, Ingo Wolfgang - Os Direitos Sociais como Direitos Fundamentais: contributo para um balanço aos vinte anos da Constituição Federal de 1988 Revista do Instituto de Hermenêutica Jurídica. 20 Anos de Constitucionalismo Democrático - E Agora? Porto Alegre-Belo Horizonte, 2008, p. 163- 206.

9 Em uma definição apertada sobre Direitos Fundamentais Sociais "Direitos sociais são direitos fundamentais do homem, caracterizando-se como verdadeiras liberdades positivas, de observância obrigatória em um Estado Social de Direito, tendo por finalidade a melhoria de condições de vida aos hipossuficientes, visando à concretização da igualdade social, e são consagrados como fundamentos do Estado democrático, pelo art. 01. `, IV, da Constituição Federal”. MORAES, Alexandre de - Direito Constitucional, $33^{\mathrm{a}}$ ed., São Paulo, Atlas, 2017. p. 154. 
da "reserva do possível", a qual tem sido recorrentemente suscitada como limite fático ao controle jurisdicional e na análise do art. $5^{\circ}, \S 1^{\circ}$, da Constituição, que deve ser interpretado como contendo um "critério de otimização"10. Tais aspectos são importantes no atual painel da fundamentalidade do direito social brasileiro, essencialmente quanto ao direito à saúde.

\subsection{Controle jurisdicional e a judicialização de medicamentos}

Quando tratamos do direito à saúde e acesso a medicamentos, enquanto realização positiva e essencial no plano das obrigações políticas ou morais que impendem sobre os Estados, imediatamente reconduzimos essa questão com o envolvimento e mobilização de recursos financeiros do Estado, que contemple, entre outros, o acesso a serviços públicos de saúde e a medicamentos distribuídos pelo governo. No fundo, está em causa prestações fáticas para garantia de acesso individual a bens sociais que o particular poderia adquirir ele mesmo, caso dispusesse dos recursos financeiros suficientes e houvesse disponibilidade no mercado para tanto.

Vinculada a tal característica, repousa a já conhecida problemática da efetiva disponibilidade do seu objeto, isto é, se o Estado se encontra em condições de dispor da prestação e por isso mesmo que a efetividade, quanto ao direito à saúde, é dependente da real existência dos meios para cumprir com a obrigação demandada ${ }^{11}$. De há muito se asseverou que o Estado dispõe apenas de capacidade limitada de dispor sobre o objeto das prestações reconhecidas pelas normas que definem os direitos sociais ${ }^{12}$, de modo que a própria limitação dos recursos constitui um limite fático à prestação desses direitos.

\footnotetext{
${ }^{10}$ Para uma análise sobre reconceitualização dos direitos sociais na doutrina brasileira, cf. MORAIS, Carlos Blanco de Morais - Curso de Direito Constitucional, Teoria da Constituição em Tempo de Crise do Estado Social, Tomo II, Vol. 2, Coimbra, Coimbra Editora, 2011, p. 555-562.

11 Assim, entre nós, MENDES, Gilmar Ferreira. A Doutrina Constitucional e o Controle de Constitucionalidade como Garantia da Cidadania - Necessidade de Desenvolvimento de Novas Técnicas de Decisão: Possibilidade da Declaração de Inconstitucionalidade sem a Pronuncia de Nulidade no Direito Brasileiro. In: Caderno de Direito Tributário e Finanças Públicas, no . 3. 1993, p. 28, ressaltando que a efetividade dos direitos sociais se encontra na dependência da atual disponibilidade de recursos por parte do destinatário da pretensão. Também KRELL, Andreas. Controle judicial dos serviços públicos básicos na base dos direitos fundamentais sociais. In: SARLET, Ingo Wolfgang (Org.). A Constituição Concretizada - Construindo pontes para o público e o privado. Porto Alegre: Livraria do Advogado, 2000, p. 40 e ss., em importante ensaio sobre o tema, acata a dependência dos direitos sociais prestacionais à existência de recursos para sua efetivação, sem, contudo, negar-lhes eficácia e efetividade.

${ }^{12}$ Cf. BrunNer, Georg. Die Problematik der sozialen Grundrechte. In: Rechtund Staar Nr. 404-405, J. C. B. Mohr (Paul Siebeck), Tubingen, 1971. p. 16.
} 
Dito isto, a reserva do possível ${ }^{13}$, também chamada de "cláusula da reserva do possível”, se consolidou no Brasil como uma teoria que encerra uma noção artificial $^{14}$ que exige um mínimo de coerência entre a realidade e ordenação normativa, a qual abrangeria além da efetiva disponibilidade fática dos recursos para a efetivação de direitos fundamentais, como o direito à saúde, outras dimensões tais quais a disponibilidade jurídica dos recursos materiais e humanos, bem como na perspectiva do eventual titular de um direito a prestações sociais, a ponderação entre proporcionalidade, exigibilidade e razoabilidade ${ }^{15}$.

Com efeito, a cláusula de reserva entende que o Judiciário não tem o condão de obrigar o Poder Público a se auto-onerar de forma desmedida para dispor daquilo, que em tese não possui. Todavia, de revés há uma grande relativização nessa abordagem, haja vista que a alegação da insuficiência por parte do Estado não pode abrigar-se somente na

\footnotetext{
${ }^{13}$ A teoria da reserva do possível como limite à intervenção judicial surgiu através do paradigmático caso numerus clausus, na Alemanha dos anos 70 , versando sobre direito ao ensino superior, em razão de demanda judicial proposta por estudantes que não haviam sido admitidos em escolas de medicina das cidades de Hamburgo e Munique em razão de política pública implementada que visava a limitação do número de vagas em cursos superiores. A jurisprudência firmada pela Corte Constitucional Federal Alemã resolveu com seguinte veredicto: entendeu que o direito a uma prestação positiva (no caso o aumento do número de vagas em cursos superiores, pois a Lei Federal Alemã assegurava o direito de escolha da profissão) encontra-se sujeito a uma reserva do possível, ou seja, daquilo que o indivíduo pode esperar de maneira racional da sociedade. Outrossim, firmou-se entendimento de que a prestação reclamada deve corresponder ao que o indivíduo pode razoavelmente exigir da sociedade, mesmo dispondo o Estado dos recursos e tendo o poder de disposição, não se pode falar em uma obrigação de prestar algo que não se mantenha nos limites do razoável. Cf. Tribunal Constitucional Federal Alemão (Bundesverfassungsgericht), proferida em 18 de julho de 1972, no caso "numerus clausus" (BVerfGE 33, 303).

${ }^{14}$ Como assevera Ana Carolina Lopes Olsen, a reserva do possível é uma noção artificial, fruto da construção humana, uma vez que não há como satisfazer simultaneamente em níveis ótimos todas as necessidades e desejos (cujos estímulos de "necessidade" são, inclusive, estudos sobre a publicidade) e que, portanto para a realidade exige-se um mínimo de coerência entre a realidade e a ordenação normativa, objeto de regulação jurídica. Cf. OLSEN, Ana Carolina Lopes. Direitos fundamentais sociais: efetividade frente a reserva do possivel. Curitiba: Juruá, 2008.

${ }^{15}$ Cf. SARLet, Ingo Wolgang e SAAVEDRA, Giovani Agostini - Judicialização, Reserva do Possível e Compliance na Área da Saúde -, R. Dir. Gar. Fund, Vitória, v. 18, n.1, 2017, p. 257-282.
} 
retórica do "obstáculo artificial" ou seja, a reserva do possível também não deve constituir-se em um dever-ser de um argumento que se apresenta como obstáculo à concretização do direito à saúde ${ }^{16}$.

Nesse sentido, Ávila (2013) afirma que o Poder Judiciário pode investir-se de proatividade, no que diz respeito à efetividade de políticas públicas, quando não há comprovação de déficit de recursos financeiros por parte do governo: “As questões de políticas públicas podem ser levadas ao conhecimento do Poder Judiciário. Assim, este tomando uma atitude ativista decide pela efetividade do direto constitucionalmente garantido, papel que lhe é próprio, afastando o argumento da "cláusula da reserva do possível" quando não devidamente comprovada à insuficiência de recursos financeiros'. (ÁVILA, 2013, p. 11).

De maneira mais moderada, há de se considerar que a disponibilidade jurídica dos recursos materiais e humanos é uma incumbência do Estado, mediante a elaboração de orçamento público previsto no art. 165 e ss da CFB, averiguação da distribuição de receitas e competências tributárias, orçamentárias, legislativas e administrativas, entre outras ${ }^{17}$. No que toca a garantia da saúde pelo Estado, a própria Constituição estabelece em seu (§ $1^{\circ}$, do art. 198) que: “[o] sistema único de saúde será financiado, nos termos do art. 195, com recursos do orçamento da seguridade social, da União, dos Estados, do Distrito Federal e dos Municípios, além de outras fontes”.

Mesmo assim, o controle jurisdicional brasileiro não tem sido efetivamente aplicado. O que vimos na realidade é "uma tendência generalizada de juízes para, mesmo na ausência da correspondente dotação orçamental e de compreensão suficiente da formatação constitucional e legal do SUS, se considerarem legitimados a impor coativamente à administração e ao legislador que aprova o orçamento a concessão individual de prestações baseadas na titularidade de direitos sociais ${ }^{18 "}$ (como o direito à saúde) sob os auspícios do art. $6^{\circ}$ combinado com art. 196, todos da CFB.

\footnotetext{
${ }^{16}$ A este propósito, cf. a ADPF 45/DF e Informativo/STF n 345/2004, em que a despeito de "obstáculos artificiais" impostos pelo Poder Público à efetividade do direito à saúde: "Não se mostrará lícito, contudo, ao Poder Público, em tal hipótese, criar obstáculo artificial que revele - a partir de indevida manipulação de sua atividade financeira e/ou político- -administrativa - o ilegítimo, arbitrário e censurável propósito de fraudar, de frustrar e de inviabilizar o estabelecimento e a preservação, em favor da pessoa e dos cidadãos, de condições materiais mínimas de existência".

${ }^{17}$ Cf. SARLET, Ingo Wolgang et. al., op. cit. p. 261.

${ }^{18}$ Cf. Novals, Jorge Reis, op. cit. 33 ss.
} 
Questões como essas ocorrem também em países subdesenvolvidos como África do $\mathrm{Sul}^{19}$. Com menos intensidade na Europa, verifica-se, por exemplo, que no regime anglo-saxônico a Court of Appel já havia analisado problemas como o dever de responder/justificar que as autoridades médicas devem apresentar no caso de recusa de tratamento com base em insuficiências orçamentais ${ }^{20}$. Por sua vez, no Canadá, a Supreme Court já tinha tido a oportunidade de considerar inconstitucional a ausência de prestação de serviços de intérprete a um doente surdo-mudo, considerando que o fundamento para a falta de recursos financeiros não era acatável para motivar a sua omissão ${ }^{21}$.

Então, na lógica interpretativa, os magistrados arrogam-se, quase sempre, na aplicação imediata do direito à saúde, através da eficácia irradiante dos direitos fundamentais ${ }^{22}$, sobretudo para a proteção de um “mínimo existencial”, segundo o qual o direito à saúde e medicamentos (como direito positivo) estariam numa umbilical relação ao núcleo essencial que seria sempre e imediatamente tutelável, entre eles: o direito à vida e a dignidade da pessoa humana ${ }^{23}$.

Entretanto, consideramos esse modelo um paliativo social, na medida em que quando se aloca uma verba para casos concretos de fornecimento de medicamentos, há um desvio forçado e não previsto na dotação orçamentária constitucional, o que acaba desregulando todo o sistema sem que a proatividade do judiciário seja a solução mais eficaz, muito menos a mais econômica, para o acesso a medicamentos não distribuidos pelo SUS.

\subsection{Efeitos da judicialização de medicamentos no Brasil}

Preocupada com o desalinhamento nas políticas públicas da saúde interna dos países, a ONU, em 2014, apresentou algumas orientações sobre universal health coverage

\footnotetext{
${ }^{19}$ Ver Minister of Health and Others $v$ Treatment Action Campaign and Others (No 2) (CCT8/02) [2002] ZACC 15; 2002 (5) SA 721; 2002 (10) BCLR 1033 (5 July 2002). No caso, o Tribunal Constitucional, em 2002, julgou inconstitucionais as medidas do governo em matéria de prevenção e tratamento da transmissão do HIV entre mães e filhos, em razão de não haver um investimento em certos medicamentos.

${ }^{20} R v$ Cambridge Health Authority, ex parte B [1995] 2 All ER 129.

${ }^{21}$ Eldridge v. British Columbia (Attorney General) [1997] 3 S.C.R. 624.

${ }^{22} \mathrm{Na}$ lição de AlEXY, os direitos fundamentais "fornecem impulsos e diretrizes para a aplicação e interpretação do direito infraconstitucional. Cf. AlEXY, Robert. Teoria dos direitos fundamentais. Trad. Virgílio Afonso da Silva. São Paulo: Malheiros, 2008, p. 524-542.

${ }^{23}$ Para a doutrina portuguesa de VIEIRA DE ANDRADE, embora os direitos sociais não integrem o regime jurídico dos direitos fundamentais de liberdades e garantias, dispõem de um "conteúdo nuclear, onde há de reconhecer-se uma especial força jurídica, pela sua referência imediata à dignidade da pessoa humana, fundamento de todo catálogo dos direitos fundamentais", cf. VIEIRA DE ANDRADE, J.C. op., cit. 359-391.
} 
(cobertura universal de saúde), através do Final Report of The WHO Consultative Group on Equity and Universal Health Coverage (Relatório final do Grupo Consultivo sobre Equidade e Cobertura Universal de Saúde da OMS) ${ }^{24}$. São três, a saber: "Distribuição justa, custo-efetividade e contribuição-justa. Respectivamente, a cobertura e utilização de serviços devem basear-se na necessidade e a prioridade deve ser dada às políticas que beneficiam os grupos menos favorecidos; prioridade deve ser dada às políticas mais custo-efetivas e as contribuições para o sistema de saúde devem basear-se na capacidade de pagamento e não de necessidade".

Ainda assim, verifica-se um avolumar significativo de ações judiciais no Brasil, movimentadas principalmente por pessoas de posses financeiras com solicitações de medicamentos de alto custo. Há um grau demasiado de ativismo judicial, que sobrepuja a esfera normativo-constitucional no que toca o dever do Estado à garantia da saúde através de políticas públicas, ficando ao talante do judiciário o desvio forçado de verbas não negligenciáveis para atender as imposições concretas, sob o alvitre uso da fundamentalidade do direito à saúde em detrimento ao ajuste financeiro do Estado para tal finalidade, através de uma "tragic choice" 25 (escolhas trágicas) entre normas Constitucionais, especialmente, entre o art. $5^{\circ}$ e o direito à vida como núcleo essencial ao direito à saúde (art. $6^{\circ}$ ) e as normas programáticas do direito à saúde do art. 196 e ss, todos da Constituição ${ }^{26}$.

Tais ações judiciais contundentes, no caso brasileiro, já são um "camuflado" sucesso no domínio da proteção à saúde. Logo, representam um peso considerável no

\footnotetext{
${ }^{24}$ WHO, (2014), Making fair choices on the path to universal health coverage. Final report of the WHO Consultative Group on Equity and Universal Health Coverage. Disponivel em http://apps.who.int/iris/bitstream/handle/10665/112671/9789241507158 eng.pdf?sequence=1 Acesso em 03 de abril de 2018.

${ }^{25}$ Para maiores desenvolvimentos sobre, Cf. CALABresi, Guido e BobitTI, Philiph - Tragic Choices, W. W. Norton \& Company, Nova York, 1978.

${ }^{26}$ O STF já decidiu claramente que defrontados os direitos fundamentais e os limites aplicáveis pelo Estado quanto às normas programáticas, opta pela fundamentalidade sem maiores ilações sobre: "Tal como pude enfatizar em decisão por mim proferida no exercício da Presidência do Supremo Tribunal Federal, em contexto assemelhado ao da presente causa (Pet 1.246/SC), entre proteger a inviolabilidade do direito à vida e à saúde - que se qualifica como direito subjetivo inalienável a todos assegurado pela própria Constituição da República (art. 5', "caput", e art. 196) - ou fazer prevalecer, contra essa prerrogativa fundamental, um interesse financeiro e secundário do Estado, entendo, uma vez configurado esse dilema, que razões de ordem ético-jurídica impõem, ao julgador, uma só e possível opção: aquela que privilegia o respeito indeclinável à vida e à saúde humanas”. Cf. STF. STA 223 AgR / PE. Relator Min. Celso de Mello. 14/04/2008. Disponível em http://redir.stf.jus.br/paginadorpub/paginador.jsp?docTP $=\mathrm{AC} \&$ docID $=630062$ Acesso em 04 de jan. de 2018.
} 
conjunto de verbas disponíveis para o setor, levando o objetivo político das decisões favoráveis a um efeito invariavelmente proporcional ou maior de retrocesso nas políticas públicas de saúde, principalmente no que tange o acesso a medicamentos. Estudos apontam que a "judicialização" da saúde, notadamente no que diz respeito os medicamentos e a sua distribuição por efeito de decisão judicial, já representava antes mesmo de 2012, 4\% do orçamento anual do Ministério da Saúde ${ }^{27}$. Em cifras, foram destinados pela União R \$ 4,5 bilhões, no interregno de sete anos, para atender a determinações judiciais de compra de medicamentos, além de depósitos judiciais. Um aumento de $1.010 \%$, entre 2010 e 2016. Somente em 2017, até o mês de agosto, os gastos pelo governo chegaram à cifra de $\mathrm{R} \$ 721,1$ milhões, com aquisição de 550 itens para atender demandas de medicamentos, e de agosto até o final do ano de 2017 estimava-se que os gastos da União, Estados e Municípios para o desiderato chegariam a R\$ 7 bilhões ${ }^{28}$.

O relatório do Conselho Nacional de Justiça (CNJ), de 2017, apresenta o número de ações, como resultado desse impacto aos cofres públicos brasileiro, apontando a soma de 1.346.931 processos judiciais em trâmite na área de saúde, dentre os quais, o pedido de fornecimento de medicamento pelo SUS se destaca como o campeão de litígios no setor público de saúde: 312.147 de ações ainda em curso $^{29}$. Ainda, o relatório filtra todas as hipóteses de pesquisa para um resultado mais preciso e concluiu que ações de fornecimento de medicamento, conjugadas com tratamento hospitalar, todas pelo SUS, resultaram no segundo lugar dentre as ações do setor, com 214.947 demandas para o mesmo período ${ }^{30}$.

Invariavelmente essa perspectiva, muito embora satisfaça os titulares que tiveram ganho no pleito, além de não resolver o problema de todos, acaba por afetar todo o sistema

\footnotetext{
${ }^{27}$ Cf. KING, Jeff - Juding Social Rights, Cambridge University Press, 2012, p. 84.

${ }^{28}$ BRASIL. Ministério da Saúde. Últimas Notícias. Agência Saúde. Núcleo de judicialização aprimora segurança do paciente em ações judiciais. Brasília, DF, 2017. Disponível em http://portalms.saude.gov.br/noticias/agencia-saude/29890-nucleo-de-judicializacao-aprimora-segurancado-paciente-em-acoes-judiciais Acesso em 25 de novembro de 2017.

${ }^{29}$ BRASIL. Conselho Nacional de Justiça (CNJ). 13a edição do Relatório Justiça em Números do Conselho Nacional de Justiça, divulgada no início de Setembro de 2017. [j]udicialização da Saúde (de natureza cível, não criminal), considerando os processos ajuizados até $31 / 12 / 2016$ e em trâmite no $1^{\circ}$ grau, no $2^{\circ}$ grau, nos Juizados Especiais, no Superior Tribunal de Justiça, nas Turmas Recursais e nas Turmas Regionais de Uniformização, totalizando na vultosa soma de 1.346 .931 (um milhão trezentos e quarenta e seis mil novecentos e trinta e um) de processos judiciais no setor da saúde Justiça em números 2017: ano-base 2016/Conselho Nacional de Justiça - Brasília: CNJ, 2017. Disponível em http://www.cnj.jus.br/programase-acoes/pj-justica-em-numeros . Acesso em 17 de abril de 2017.

${ }^{30}$ O Relatório prevê o cadastramento separado dos assuntos "Fornecimento de medicamentos" e "Tratamento médico-hospitalar" ou em conjunto ("Tratamento médico hospitalar e/ou fornecimento de medicamentos"), por isso que foram somadas todas as hipóteses para um resulto mais preciso.
} 
e a própria Constituição, agravando as desigualdades sociais, haja vista que recursos que poderiam ser utilizados na compra de medicamentos pelo SUS, bem como em inovação no setor dos fármacos, por exemplo, são alocados a tratamentos mais caros e geralmente "consumidos" por pessoas com alguns recursos: "pois essa massa de excluídos não vem ao sistema, não recorre a tribunais, não pode fazer um “uso alternativo do Direito", porque nem sequer tem condições subjetivas e objetivas para tanto. "Quem, à primeira vista, beneficia da redistribuição dos fundos políticos assim operada é preferencialmente uma camada social instruída, organizada sindicalmente ou economicamente mais forte, que pode pagar advogados que dominam as debilidades do sistema e que pode pagar uma justiça que não está no alcance de todos" 31 .

Assim se chega à conclusão teórica de que sempre que há titularidade do direito à saúde isso significa a possibilidade de ação judicial contra o Estado reivindicadora da prestação social em causa e, mais, já há uma grande probabilidade de o juiz decidir positivamente à prestação independentemente de prévia e correspondente decisão orçamental. Essa lógica, em alguns casos, pode aprioristicamente revelar-se uma forma de coesão social, mas em outros acabou por estimular o acometimento de fraudes no setor.

É o caso da “Operação Asclépio 32", em 2013, que teve por objetivo a importação dos EUA de medicamento de alto custo que ainda não havia sido aprovado pela Agência de Vigilância Sanitária (ANVISA), com o pano de fundo de fornecimento de medicamento, perquirido por pacientes, através de ação judicial. Consequentemente, até o crime ser deflagrado, a ordem judicial já havia se consumado, determinando o SUS a adquirir medicamentos por quantias milionárias, causando desnecessariamente uma erosão aos cofres públicos às custas de toda a população brasileira.

\footnotetext{
${ }^{31}$ [Nota do original] NovaIs, Jorge Reis, op. cit. 33 ss.

32 Operação Asclépio (batizada com o nome do deus grego da medicina) foi deflagrada em 2013 pela Corregedoria Geral da Administração (CGA) e a Polícia Civil de São Paulo. In casu, os pacientes, orientados pelos médicos, ingressavam no Poder Judiciário exigindo fornecimento gratuito do medicamento denominado "lomitapida". Cada cápsula de Juxtapid (lomitapida), da empresa americana Aegerion Pharmaceuticals, custava cerca de US\$ 1.000 por dia. Á época, US\$ 30 mil por mês e US\$ 360 mil por ano. Mais de R\$1 milhão por paciente. O referido medicamento havia sido aprovado nos EUA para uma doença raríssima. À época, suspeitou-se que os brasileiros estariam sendo usados como cobaias para que o medicamento fosse aprovado nos EUA. Considerada uma "verdadeira máfia do medicamento", o Corregedor Geral da Administração decidiu encaminhar cópia do procedimento elaborado pela Corregedoria ao FBI. Disponível em http://www.saopaulo.sp.gov.br/sala-deimprensa/release/corregedoria-e-policia-civil-deflagram-operacao-asclepio/ e https://epoca.globo.com/vida/noticia/2016/06/os-falsos-doentes-de-r-95-milhoes.html Acesso em $10 \mathrm{de}$ abril de 2018.
} 
Medidas primárias estão sendo implementadas para conter desvios na agenda da saúde com resultados positivos, como está a ocorrer no Estado de São Paulo. Recentemente, o Tribunal de Contas do Município (TCM) estimou que estratégias de combate à "judicialização" da saúde naquele Estado, no ano de 2017, envolvendo toda a governança, trouxe uma economicidade para a pasta de $\mathrm{R} \$ 61.028 .383,60^{33}$. Os números da judicialização também são reflexos da atecnia de juízes sobre muitas implicações referentes a outras áreas que escapam do dominio jurídico dos magistrados. Para o proveito dessa situação, escritórios de advocacia especializados se esmeram na causa de pedido de medicamentos, na sua maioria de alto custo, a fim de obter ganho de causa certo em favor de seus clientes.

Visando esse déficit, o Ministério da Saúde lançou ferramenta para subsidiar o judiciário com informações necessárias de modo a estimular um diálogo judicial entre os atores envolvidos na judicialização da saúde - promotores, procuradores, advogados, juízes, desembargadores e ministros, e instrumentaliza-los com questões técnicas, baseadas em evidências científicas para a solução das demandas analisadas pelos magistrados. Como proposta alternativa, faz-se necessário nesses temas um programa de ensino voltado a todos os atores envolvidos, principalmente os juízes, baseado em um modelo já ocorrido nos EUA, em que objetivou a reciclagem em novas doutrinas de Direito e Economia às pessoas e aos juízes ${ }^{34}$.

Finalmente, se vimos diuturnamente o judiciário brasileiro sensível às aspirações e exigências da população nesse levante, parece-nos mais coerente e crível refletirmos que a desigualdade social brasileira não é unicamente um problema decorrente tão somente de um judiciário ativo, mas entender os motivos da negligência legiferante e ineficiência da administração pública que, como veremos mais adiante, se deixam perpetuar no limbo dessa tensão assistindo a doutrina apontar frequentemente a judicialização de medicamentos e da saúde, em seu gênero, como "o" (ênfase adicionada) ponto nevrálgico

\footnotetext{
33 Disponível em http://www.escoladecontas.tcm.sp.gov.br/images/conteudo-palestras/impacto-dajudicializacao-no-SUS.pdf Acesso em 25 de maio de 2018.

${ }^{34}$ Segundo o economista Joseph Stiglitz, economistas da Escola de Chicago ao defenderem algumas teorias acerca de práticas monopolistas e anticompetitivas, criaram novas doutrinas sobre o tema. Com efeito, foi elaborado um programa "educacional" para orientar as pessoas, sobretudo os juízes acerca dessas novas doutrinas de Direito e Economia. "O timing foi irônico: os tribunais norte-americanos deixavam-se levar pelas noções de que a disciplina econômico, conhecido por teoria dos jogos, explicava o modo como um comportamento conspiratório pode ser mantido de forma tácita durante longos períodos de tempo". Cf. Stiglitz, Joseph. O preço da desigualdade. (Traduzido por Dinis Pires; rev. Sandra Areias). - $1^{\text {a }}$ ed., reimp. - Lisboa: Bertrand, 2014. p. 107 e 108.
} 
e uma das causas principais de uma retração do Estado social de direito brasileiro no tocante à saúde.

Por isso, a mitigação de implicações como a judicialização de medicamentos no Brasil ainda está no campo da resiliência, o que suscita uma atenção especial na análise de outros subsistemas que poderão de certo modo esclarecer que as complicações referentes ao acesso a medicamentos no Brasil são reflexos também da interferência direta ou indireta de alguns atores, do setor privado farmacêutico, bem como da ineficiência do setor público. Essas perspectivas nos convidam ao estudo interdisciplinar do fenômeno da judicialização de medicamentos com implicações do direito de propriedade industrial brasileiro (particularmente, a duração do prazo de validade de patentes na lei interna).

\section{PROTEÇÃO INTELECTUAL PATENTÁRIA E MEDICAMENTOS}

As patentes se apresentam como um mecanismo significativo de troca, fazendo parte do sistema de propriedade intelectual de um país, cujo objetivo é garantir a propriedade ou exclusividade do trabalho inventivo. Nas palavras de Garcez Júnior et al:

O sistema de propriedade intelectual de um país é criado para garantir a propriedade ou a exclusividade resultante da atividade intelectual nos campos industrial, científico, artístico e literário. Dentro deste sistema, as patentes apresentam-se como um importante mecanismo de troca. Aceita-se oferecer o privilégio da proteção contra a concorrência, no curto prazo, em troca dos frutos da inovação a longo prazo (JÚNIOR et. al., 2017, 172) ${ }^{35}$.

Curiosamente, o primeiro medicamento que mudou o mundo, a "penicilina", de 1928, nunca foi patenteado pelo seu inventor, Alexander Fleming. A justificativa para a atitude nobre deveu-se ao fato calamitoso de algumas infecções epidêmicas que eram a maior causa de morte da época, até então incuráveis, e especialmente em razão da $2^{\mathrm{a}}$ guerra mundial, o que mais tarde motivou sua produção em massa por mais dois outros cientistas. Em 1948, o trabalho colaborativo dos três cientistas resultou no compartilhamento do título do Prêmio Nobel de medicina ${ }^{36}$.

\footnotetext{
${ }^{35}$ Cf. JÚNIOR, Sílvio Sobral Garcez e MOREIRA, Jane de Jesus da Silveira: O Backlog de patentes no Brasil: o direito à razoável duração do procedimento administrativo. Revista Direito GV | São Paulo | v. 13 n. 1 | 171-203 | jan-abr 2017. p. 172.

36 Cf. PAtol, J. Bras. Nossa capa: Alexander Fleming e a descoberta da penicilina, Med. Lab. vol.45 no.5 Rio de Janeiro Oct. 2009. Ver também BBC, Historic Figures: Alexander Fleming (18811955). Disponível em http://www.bbc.co.uk/history/historic_figures/fleming_alexander.shtml. Acesso em 08 de fevereiro de 2018 .
} 
Em verdade, muitas empresas optaram por não patentear suas inovações, como a Coca-Cola que tem confiado seus segredos comerciais e industriais há muito tempo e mesmo assim obtém retornos vultosos a partir da "vantagem do pioneiro" (first mover advatage), sendo uma das maiores marcas e empresas conhecidas mundialmente. Embora atualmente no mundo da alta tecnologia se verifique algum sucesso de empresas de oferta de serviço com abordagem de código aberto (open source) ${ }^{37}$ bem sucedida, no setor farmacêutico quase não há modelos de open source a exemplo da $\mathrm{DNDi}^{38}$, tampouco outros registros históricos como os de Fleming.

Para as empresas farmacêuticas, a criação do monopólio de patentes justifica-se que sem a capacidade de apropriar os retornos das atividades inovadoras concedidas por esses monopólios, a pesquisa, a inovação e o trabalho criativo estariam subestimados pelo mercado, no caso de não haver nenhum apoio direto do governo. Então, a lógica básica é que para a indústria farmacêutica inovadora de medicamentos de referência, se a sua produção for vendida em um mercado competitivo, o preço genérico reconduziria ao custo marginal de produção e não permitiria o lucro suficiente para recuperar o custo da criação do trabalho. Com efeito, a pesquisa é incentivada, mas "no uso corrente do conhecimento $^{39}$ ",

Essa visão original acerca da propriedade intelectual, enceta responsabilidades de disseminação e incentivo à inovação, como contrapartida conferida através do monopólio de patentes. Pese tenha seus méritos, de há muito também vem sendo contestada. Isso pode ser um problema, a partida de que a propriedade intelectual não pode ser um fim em si mesma, sobretudo dada a sua importância de função à política pública, uma vez que diz respeito à saúde e acesso a medicamentos ${ }^{40}$.

\footnotetext{
${ }^{37}$ Segundo pesquisa recente, mais de $70 \%$ das empresas na América Latina usam algum software open source. O principal motivo é o baixo custo (52\%), independência de provedor $(46 \%)$ e capacidade de personalizar o código-fonte para desenvolver aplicativos (41\%). Disponível em http://computerworld.com.br/mais-de-70-das-empresas-no-brasil-usam-algum-software-open-source Acesso em 04 de maio de 2018,

${ }^{38}$ A Iniciativa Medicamentos para Doenças Negligenciadas (DNDi, sigla em inglês) é um exemplo útil de mecanismo não patentes, onde busca desenvolver medicamentos para doenças que afetam quase que exclusivamente países em desenvolvimento. A inicativa é financiada por organizações de assistência, instituições filantrópicas privadas e instituições acadêmicas. A pesquisa está disponível em open source para incentivar a pesquisa e tornar-se desnecessária a duplicidade de experimentos clínicos. Para maiores desenvolvimentos sobre, ver STIGLITZ, Joseph E. et. al. Op. Cit. p. 70.

${ }^{39}$ Cf. BAKer, Dean, Jeyadev Arjun, Stiglitz, Joseph E. (2017) Inovação, Propriedade Intelectual e Desenvolvimento: Um conjunto melhor de abordagens para o século 21. (Traduzido por James Tibúrcio). accessibsa, p. 10. Disponível em http://accessibsa.org/arguments-port/ Acesso em 03 de janeiro de 2018.

${ }^{40}$ Sobre o atual cenário do monopólio das patentes e propriedade intelectual: "Este equilíbrio está se perdendo. É um problema porque a propriedade intelectual não pode ser um fim em si mesmo. Ela é também uma política pública, uma vez que no setor saúde, por exemplo, está relacionada ao acesso a
} 
O monopólio das patentes, não afeta somente a eficiência estática das patentes, mas o caminho dinâmico da inovação. Em estudo recente, STIGLITZ et. al.(2017) ${ }^{41}$, afirmam que a patente estabelece restrições imediatas, retirando do "conjunto de conhecimentos" ideias que outros inventores possam usar. É o que acontece com os modelos de utilidade - patenteamento de "pequenos passos", os quais poderiam encorajar a novas descobertas. Ainda, os autores alertam ao "emaranhado de patentes" fracas que não tem incentivado a inovação, mas encorajado o litígio e que "mesmo nos EUA e outros países industrializados avançados, o sistema de patentes se encontra em período de crise".

A esse despeito, recentemente a Suprema Corte dos EUA decidiu que os genes humanos não podem ser patenteados, haja vista que o DNA ocorre naturalmente e é um produto da natureza. A decisão baseia-se no caso da empresa americana Myriad Genetics v. Assoc. for Molecular Pathology ${ }^{42}$, a qual detinha a patente dos genes BRCA1 e BRCA2, cujas mutações indicam risco maior de câncer de mama e ovário. O resultado da jurisprudência, que despretensiosamente acabou por contribuir para uma experiência sobre custos e benefícios da patente, revelou na sequência do domínio público uma explosão significativa de novas pesquisas sobre o tema, com maior teor de qualidade, a um preço muito mais baixo ${ }^{43}$.

De há muito essas questões levantam a necessidade alternativa de financiamento e incentivo à pesquisa, que não centradas somente na retórica das patentes, mas em modelos que no panorama atual já estão em uso. É o exemplo da National Science Foundation, nos EUA, que financia pesquisa e educação na maioria dos campos da ciência e engenharia, por meio de doações e acordos de cooperação para mais de 2.000 universidades, dentre outras ${ }^{44}$.

Todavia, países em desenvolvimento, como o Brasil, se debatem com questões orçamentais restritas e com uma capacidade ínfima de centralizar a P\&D (em inglês, research and development, ou $R \& D$ ) farmacêutica em financiamentos diretos ou

medicamentos", declarou a cientista política SUSAN SELL em conferência no ISAGS (Instituto Suramericano de Gobierno em Salud), 2014, Argentina, sobre "propriedade intelectual e acesso a medicamentos. Disponível em http://isags-unasur.org/wp-content/uploads/2018/03/ev-1530-ling-1-anx387.pdf Acesso em 05 de fevereiro.

${ }^{41}$ Cf. STIGLitZ, Joseph E. et. al. Op. Cit. p. 12.

${ }^{42}$ Assoc. for Molecular Pathology v. Myriad Genetics, Inc., 569 U.S. (2013)

${ }^{43}$ Cf. STIGLitZ, Joseph E. et. al. Op. Cit. p. 17.

${ }^{44}$ National Science Foundation. NSF. 1950. Disponível em: https://www.nsf.gov/funding/aboutfunding.jsp Acesso em 09 de fevereiro de 2018. 
indiretos. Por outro lado, se defronta com uma realidade peculiar que lhe custa muito mais caro e que ao invés, poderia estimular a indústria nacional de medicamentos. É o caso da extensão no prazo de validade de patentes prevista no ordenamento jurídico interno brasileiro que alimenta o backlog de patentes $^{45}$ e resulta em consequências deletérias aos cofres públicos e a toda a sociedade civil.

Desse modo, as proteções à propriedade intelectual cada vez mais fortes, além de poderem não reconduzir necessariamente a um aumento na descoberta de novas entidades químicas, favorecendo o incentivo à indústria farmacêutica local, bloqueiam a entrada de genéricos no mercado o que escoa naturalmente em impactos econômicos vultosos aos cofres públicos, quando o governo os compra com valores subestimados, tanto diretamente, quanto indiretamente (através de determinação judicial), dinheiro esse desviado às custas do monopólio que poderia ser utilizado no próprio desiderato da saúde, para o benefício social de toda a comunidade e para o fortalecimento econômico do Estado.

\title{
3.1 Privilégio temporário de patente na constituição brasileira e a Lei $n^{\circ}$ 9.279/96 (Lei de Propriedade Industrial)
}

A patente é um catalisador da atividade econômica tecnológica, mediante um direito temporário, cuja previsão está contida na Constituição como garantia fundamental no Artigo $5^{\circ}$, XXIX, a ver:

\begin{abstract}
Art. $5^{\circ}$. Todos são iguais perante a lei, sem distinção de qualquer natureza, garantindo-se aos brasileiros e aos estrangeiros residentes no País a inviolabilidade do direito à vida, à liberdade, à igualdade, à segurança e à propriedade, nos termos seguintes:

[...] XXIX - a lei assegurará aos autores de inventos industriais privilégio temporário para sua utilização, bem como proteção às criações industriais, à propriedade das marcas, aos nomes de empresas e a outros signos distintivos, tendo em vista o interesse social e o desenvolvimento tecnológico e econômico do País; [...].
\end{abstract}

\footnotetext{
${ }^{45}$ Sobre backlog de patentes, no entendimento de Rafaella Dias: "A palavra backlog significa em tradução literal: "acumulo". Substantivo que se trata de um conceito relacional, cujo significado só acaba por ser descoberto através da análise do objeto que se relaciona, dado que por óbvio, o "acúmulo" é de algo. No caso em apreço, ao relacionarmos o backlog com demora na análise de patentes, diríamos que o "acúmulo" poderia ser de patentes ou de trabalho. Assim, backlog, portanto, encerra a ideia de excesso à análise de patentes: o ponto de partida para diversos conceitos a um mesmo fim. Cf. GONÇALVES, Rafaella Dias, PIDCC, Aracaju/Se, Ano VII, Volume 12 nº 03, p.046 a 081 Out/2018.
} 
Para SILVA $(2010)^{46}$, pese a proteção à propriedade intelectual esteja localizada entre as garantas individuais, a mesma não possui natureza de direito fundamental e, portanto, depende de legislação ordinária, tratando-se de norma com eficácia limitada. Ainda assim, a proteção temporária à propriedade intelectual é assegurada constitucionalmente, através de lei, desde que observadas sua função social (interesse social) e pelo desenvolvimento econômico do país, consoante cláusula finalística do supracitado artigo. BARBOSA (2009) ${ }^{47}$ pondera que: [a] cláusula final, novidade do texto atual, torna claro que os direitos relativos à Propriedade Industrial não derivam diretamente da Constituição brasileira de 1988, mas de lei ordinária; e tal lei só será constitucional na proporção em que atender aos seguintes objetivos: a) visar ao interesse social do país; b) favorecer o desenvolvimento tecnológico do país; c) favorecer o desenvolvimento econômico do país. Desse modo, o relevante interesse público envolvido na parte in fine do dispositivo constitucional, impõe que o direito exclusivo só seja concedido mediante a presença desses objetivos legais e constitucionais.

Além do clássico conceito que apresentamos anteriormente, a "patente é também um instrumento de política de empresa, visto que o direito exclusivo confere ao titular da patente a oportunidade de explorar a invenção, sem concorrência, durante um período determinado; ela serve, também, como meio de reservar o mercado de um determinado produto" ${ }^{48}$. Desse modo, o privilégio de exploração patentária pode ser utilizado como instrumento de reserva de mercado, limitando a concorrência o que pode provocar o efeito inverso: de obstáculo ao desenvolvimento tecnológico.

A despeito da relevância do sistema de proteção patentária com vistas ao progresso tecnológico e em combate à referida "reserva de mercado", o princípio da função social da propriedade ao sistema de patentes se faz codição sine qua non e está prevista na constituição, no art. 5, XXIII: “a propriedade atenderá a sua função social”. A jurista brasileira PIOVESAN $(2007)^{49}$, em estudo sobre a relação entre direitos humanos e

\footnotetext{
${ }^{46}$ Cf. Silva, José Afonso da. Comentário contextual à Constituição. 7. ed. São Paulo: Malheiros, 2010, p. 127.

${ }^{47}$ Cf. BARbosa, Denis Borges. A propriedade intelectual no século XXI: estudos de Direito. Rio de Janeiro: Lumen Juris, 2009, p. 663.

${ }^{48}$ Cf. LABRUNIE, Jacques. Direito de patentes: condições legais de obtenção e nulidades. Barueri, 2006, p. 24.

49 "Na visão do Comitê os próprios delineamentos conceituais do direito à propriedade intelectual hão de ser redefinidos considerando a necessária proteção dos direitos sociais, econômicos e culturais. Isto é, à luz dos direitos humanos, o direito à propriedade intelectual cumpre uma função social, que não pode ser obstada em virtude de uma concepção privatista deste direito que eleja a preponderância incondicional dos
} 
propriedade intelectual, concluiu que a proteção da propriedade intelectual possui limites e que deve ser ponderada conforme sua função social, em razão de seu impacto nos direitos sociais, econômicos e culturais. Isso equivale a uma "relativização" da propriedade, na medida que a norma constitucional não somente busca garantir privilégio de exploração de propriedade intelectual, mas também assegura aos demais atores, consumidores e investidores, que findo o decurso de prazo legal da proteção, o monopólio de exploração da invenção industrial será extinto ${ }^{50}$.

Como vimos, ao legislador ordinário cabe a ponderação constitucionalmente equilibrada entre os direitos fundamentais e o interesse coletivo, principalmente no caso das patentes farmacêuticas, cuja proteção resvala no $P \& D$ da indústria no setor que aposte tanto no desenvolvimento de medicamentos inovadores quanto na justa concorrência com a abertura à indústria de genéricos ${ }^{51}$. $\mathrm{O}$ direito constitucional não faz e nem pode fazer privilégios a um ou ao outro, mas certo é que o acesso a medicamentos à luz da proteção constitucional da propriedade intelectual, somente terá sua função social efetivada se objetivar à promoção do direito fundamental à saúde e o fomento à inovação no setor no país.

direitos do autor em detrimento da implementação dos direitos sociais, como o são, por exemplo, à saúde, à educação e à alimentação. Observe-se ainda que, via de regra, o conflito não envolve os direitos do autor versus os direitos sociais de toda uma coletividade; mas, sim, o conflito entre os direitos de exploração comercial (por vezes abusiva) e os direitos sociais da coletividade. [...] Extrai-se, assim, o dever dos Estados de alcançar um balanço adequado entre a proteção efetiva dos direitos do autor/inventor (lembrando que, via de regra, quem acaba por prejudicar os interesses sociais e os direitos humanos são os detentores dos direitos de exploração comercial de determinada obra ou invento) e a proteção dos direitos sociais à educação, alimentação e saúde, bem como aos direitos culturais e de desfrute dos progressos científicos. Nesta ponderação de bens, o direito à proteção da propriedade intelectual não deve ser considerado ilimitado ou absoluto, na medida em que a propriedade intelectual tem uma função social. Os regimes jurídicos de proteção da propriedade intelectual devem ser analisados sob a perspectiva de seu impacto no campo dos direitos humanos". Cf. PIOvesAn, Flávia. (2007) Direitos humanos e propriedade intelectual. 2007, 20 p. 20 21 Disponível Acesso em:http://bibliotecadigital.fgv.br/dspace/bitstream/handle/10438/2665/CL01\%20\%20Flavia\%20Piovesan \%20Direitoshumanosepropriedadeintelectual.pdf?sequence=3 Acesso em: 03 de jan. 2018.

${ }^{50}$ Para maiores desenvolvimentos sobre a relativização da propriedade, com privilégios temporários, cf. BASSO, Maristela. Comentário ao art. $5^{\circ}$, XXIX. in: CANOTILHO, J.J. Gomes; MENDES, Gilmar F.; SARLET, Ingo W.; StReCK, Lenio L.(coords.). Comentários à Constituição do Brasil. São Paulo: Saraiva/Almedina, 2013, p. 335.

${ }^{51}$ Compreende-se que o sistema de patentes apresenta-se como o mais eficaz no equilíbrio entre os interesses em questão: por um lado, procura responder aos interesses do inventor no sentido em que atribui um direito de exclusivo de exploração do bem objecto de patente e, por outro, busca responder aos interesses da comunidade em virtude de exigir, ao titular desse direito privativo, a divulgação da tecnologia patenteada e respectivos meios de execução ao garantir o seu livre acesso no termo do período de protecção. Está em causa a concessão ao inventor de um monopólio legal, durante um determinado lapso de tempo, findo o qual a invenção cai no domínio público. Para maiores desenvolvimentos, cf: MARQUES, João Paulo Remédio (II), Medicamentos Versus Patentes - Estudos de Propriedade Industrial, $1^{\text {a }}$ ed., Coimbra, Coimbra Editora, 2008. 
É com base nesse pano de fundo que a Lei $n^{\circ}$ 9.279/96 (Lei de Propriedade Industrial) vigora no Brasil, vindo a regular direitos e obrigações sobre a propriedade industrial. A mesma, além de tornar plena a norma constitucional de eficácia limitada no art. $5^{\circ}$. XXIX, foi criada com o objetivo de adaptar-se às regras de propriedade intelectual (latu sensu) do Acordo TRIPS ao abrigo da $\mathrm{OMC}^{52}$, com o fito de regulamentar os direitos relativos à propriedade industrial (strictu sensu), exceto as questões relativas aos direitos de $\operatorname{autor}^{53}$. E mais particularmente, por força do princípio da não-discriminação (art. 27\%1 do Acordo TRIPS), o Brasil assumiu o compromisso internacional e adaptou sua legislação para reconhecer, dentre outros, produtos farmacêuticos patenteáveis no ordenamento jurídico brasileiro, observadas as situações excepcionais no período de transição ${ }^{54}$.

Com efeito, os direitos exclusivos do titular da patente foram consagrados no artigo 42, inciso I, da LPI onde dispõe que: “[a] patente confere ao seu titular o direito de impedir

\footnotetext{
$52 \mathrm{O}$ resultado da imbricação de esforços de potências, faz nascer no âmbito da OMC o Acordo TRIPS (Trade-Related Aspects of Intellectual Property Agreement)2, que de longe representa o tratado internacional de maiorabrangência no tocante a propriedade intelectual. Trade-Related Aspects of Intellectual Property Rights. (N.T.). Disponível em https://www.wto.org/english/docs_e/legal_e/27trips.pdf Acesso em 12 de fev. de 2017.

${ }^{53} \mathrm{O}$ conceito de propriedade intelectual como "super estrutura jurídica", abarca, por um lado, a propriedade industrial e, por outro, direitos de autor, conexos (e também os copyrights). Ao que nos interessa, a primeira definição de direito industrial pertence a Renouard, segundo o qual " [o] direito industrial abarca as relações legais e jurídicas que se criam entre os homens para a produção das coisas e a aplicação das coisas aos serviços humanos". Cf. Gonçalves, Luís Manuel Couto, Manual de Direito Industrial: Patentes; Desenhos ou Modelos; Marcas; Concorrência Desleal, $2^{\mathrm{a}}$ ed., Coimbra, Almedina, 2008, p. 27.

${ }^{54} \mathrm{O}$ Artigo. $9^{\circ}$ do antigo Código de Propriedade Industrial (Lei 5.772/71) continha disposição expressa que impedia tal proteção. Com a transição para a lei atual 9.279/1996, para adaptação ao plano internacional assumido com a assinatura do Acordo TRIPS, o ordenamento jurídico brasileiro objetivou não prejudicar os depositantes que poderiam deixar em "standby" o requerimento do deposito até que a nova lei entrasse em vigor, para que então passasse a ser processados e examinados pelo INPI até o ano de 2004, cujo prazo das patentes seriam somente até 20 anos contados da data do depósito (caput do Art. 40 da Lei 9.279/1996). Assim: "[t]al sistema de transição objetivou não prejudicar os depositantes, que teriam, com o depósito, a delimitação de um marco temporal para avaliação do estado da técnica, conquanto o processamento do pedido não fosse ainda possível em razão da ausência de base legal para tanto. Esses requerimentos, em razão da natureza do sistema implementado, ficaram na "caixa de correio" (mailbox) do INPI, aguardando a entrada em vigor da nova legislação, para, então, serem processados e examinados. Assim, consoante disposto no TRIPS (sobretudo no art. 70.8), começou-se a aceitar o depósito no INPI, de 1/1/1995 até 14/5/1997, de pedidos para essas chamadas patentes mailbox (relacionadas às áreas agroquímica e farmacêutica) cuja regulamentação específica, acrescida da parte administrativa/operacional a cargo da autarquia, foi estabelecida tão somente com a edição da Medida Provisória 2.006/99 (posteriormente convertida na Lei 10.196/01, que modificou a LPI)[...] Tratando-se, contudo, de patentes excepcionalmente depositadas pelo sistema mailbox, a Lei de Propriedade Industrial, em suas disposições finais e transitórias (art. 229, parágrafo único), estabeleceu regra expressa assegurando proteção limitada unicamente ao lapso de 20 anos contados do dia do depósito (conforme estipulado pelo citado art. 40, caput)".
} 
terceiro sem o seu consentimento, de produzir, usar, colocar à venda, vender ou importar com estes propósitos um [...] produto objeto de patente".

Indubitavelmente, a norma assume um relevo importante no panorama atual, em que se reconhece a patenteabilidade dos produtos farmacêuticos no Brasil, sendo relevante a proteção constitucional ao esforço individual da criação, por meio das patentes ${ }^{55}$. Ao mesmo tempo, verifica-se que após o Brasil começar a conceder patentes de produtos e processos farmacêuticos, o preço dos fármacos se elevou demasiadamente ${ }^{56}$. Esse fato foi motor propulsor para que em 1999, o Brasil adotasse a “Lei dos Genéricos", Lei 9.787/199957.

Desde então, o interesse social em acessar as patentes farmacêuticas através de medicamentos genéricos ainda encontra barreiras e uma delas repousa na prorrogação da vigência das patentes prevista no parágrafo único do artigo 40 da LPI. Tais práticas são conhecidas pela literatura como evergreening ou perenização, que permitem o monopólio de uma patente durar muito mais tempo, talvez até indefinidamente, atrasando a entrada de genéricos no mercado ${ }^{58}$.

\subsection{O parágrafo único do artigo 40 da lei 9.279/1996 (extensão do prazo de validade de patentes)}

O parágrafo único do art. 40 da LPI prevê um prazo de vigência mínimo a contar da concessão da patente, a ver:

\footnotetext{
Artigo 40: A patente de invenção vigorará pelo prazo de 20 (vinte) anos e a de modelo de utilidade pelo prazo 15 (quinze) anos contados da data de depósito. Parágrafo único. O prazo de vigência não será inferior a $10(\mathrm{dez})$ anos para a patente de invenção e a 7 (sete) anos para a patente de modelo de utilidade, a contar da data de concessão, ressalvada a hipótese de o INPI estar impedido de proceder ao exame de mérito do pedido, por pendência judicial comprovada ou por motivo de força maior.
}

Da leitura se extrai que aplicada a exceção prevista nesse parágrafo, será garantido ao titular uma vigência que corresponda a um mínimo de 10 anos para a patente de

\footnotetext{
${ }^{55}$ Cf. MACHADO, Jonatas et. al., op. cit., p. 163.

${ }^{56}$ Cf. KweItel, J. e ReIS, R. op., cit.

${ }^{57}$ BRASIL. LEI N ${ }^{\circ} 9.787$, DE 10 DE FEVEREIRO DE 1999. Altera a Lei no 6.360 , de 23 de setembro de 1976, que dispõe sobre a vigilância sanitária, estabelece o medicamento genérico, dispõe sobre a utilização de nomes genéricos em produtos farmacêuticos e dá outras providências. Brasília, DF. Disponível em http://www.planalto.gov.br/ccivil_03/Leis/L9787.htm Acesso em 20 de maio de 2017.

${ }^{58}$ Cf. STIMAC, Alexander, op., cit., p. 6.
} 
invenção e 7 ao de modelo de utilidade, a contar da concessão da patente, prevista no art. $38 \S 3^{\circ}$, o que poderá resultar em uma proteção de mais de 20 anos. A dita extensão, inicialmente, foi incluída na legislação brasileira para ser uma exceção ao regime de vigência geral (prazo vintenário) ${ }^{59}$. Todavida, a exceção tornou-se regra ${ }^{60} \mathrm{em}$ : $38 \%$ das cartas-patentes expedidas para pedidos depositados em 1997, 85,5\% para pedidos depositados em 1998 e praticamente $100 \%$ das patentes concedidas para medicamentos depositadas no Brasil após $1999^{61}$ ".

O crescimento exponencial da extensão de patentes por força legal, reflete-se na alarmante situação atual que leva o Brasil a liderar o ranking mundial de atraso na análise de patentes pela administração. E, ainda que por mora do INPI, não constitui instrumento compatível com a Constituição, conforme prelaciona João da Gama Cerqueira:

\begin{abstract}
A prorrogação do prazo de duração do privilégio é medida que não encontra nenhuma justificativa e que só poderá dar lugar a abusos e injustiças. (...) Não receamos errar afirmando que os interesses nacionais e os interesses da coletividade não se conciliam nunca com a prorrogação do prazo dos privilégios, exigindo, ao contrário, a sua extinção no prazo normal. De fato, como pode a Nação ou a coletividade ter interesse na permanência de um privilégio que cerceia a liberdade de todos e cuja exploração exclusiva só ao seu concessionário traz benefício? Aliás, a incoerência da lei mais se patenteia quando faz depender a prorrogação do prazo de "pedido devidamente comprovado", pois esse pedido somente poderá ser feito pelo único interessado no prolongamento do privilégio, isto é, pelo concessionário, o qual representa
\end{abstract}

\footnotetext{
${ }^{59}$ Mesmo assim, os fundamentos da prorrogação excepcional careceram de iluminação judicial ao longo dos anos, na medida em que a interpretação distorcida poderia ter conduzido aos caos monopolista de muitos atores da indústria farmacêutica que tentaram aproveitar a medida expansiva para amplicar a proteção de privilégio, sem que houvesse precedentes para isso. É o caso de patentes "caixa de correio" (em inglês mailbox). O Artigo 229-B prevê uma regra transitória especial em que os pedidos de patentes mailbox (antigas patentes que tiverem o privilégio de serem processadas e examinadas pelo INPI, com a vigência da nova lei 9.179/1996) deveriam ser examinadas pelo órgão administrativo até 31/12/2004. Mas, algumas patentes somente foram concedidas após esse prazo, perdendo o objeto em razão do lapso temporal, o que motivou uma série de ações pelos titulares na tentativa de estender o prazo de validade de patentes ao abrigo do parágrafo único, do Artigo 40 da LPI. Outrossim, em decisão recentíssima de 2018, o STJ entendeu que: "[v]ale dizer, o fato de o texto do art. 229, da LPI dispor que referido prazo de vigência está somente "limitado" àquele previsto no "caput" do artigo 40 afasta, como corolário, a incidência do prazo do respectivo parágrafo único (10 anos contados da concessão). Este dispositivo legal (art. 40, parágrafo único, da LPI), ademais, não deve incidir sobre a presente hipótese fática por estar inserido em capítulo da lei que versa sobre regras gerais aplicáveis ao sistema ordinário de patentes, não podendo irradiar efeitos sobre matéria a qual foi conferido tratamento especial pela mesma lei (sistema transitório mailbox)". Para maiores desenvolvimentos, vide supra nota 263.

${ }^{60}$ Como bem observado pela jurisprudência, "se lembrarmos que em relação aos inventos, o domínio público é a regra e a proteção, exceção, sempre condicionada a inúmeros fatores e por prazo sempre limitado" Cf. TRF- $2^{\mathrm{a}}$ Região, $2^{\mathrm{a}}$ Turma Especializada. AC 2005.51.01.534005-6. Des. André Fontes. DJ 11.12.2007.

61 Ver JannuzZI AHL, VAsconcellos AG. Op. Cit. p. 214.
} 
seus interesses pessoais e não os interesses nacionais ou os da coletividade (CERQUEIRA, 2010, 159) ${ }^{62}$.

Há uma sinestesia deletéria entre o atraso do INPI e a sua salvaguarda com a prorrogação da validade de patentes que deveria ser combatida com eficiência e não com uma "compensação perene" suportada pela sociedade. Tal, viola a função social da propriedade, além de divergir com o interesse público. Ademais, em detrimento desse último há uma "camada" que se beneficia com a famigerada perenização, pois a par da “exceção" do artigo 40, a LPI brasileira já protege os interesses do requerente da patente muito antes da mesma ser concedida (se for aprovada) e cair no domínio público nos Artigos 42 e 44.

Para BARBOSA $(2015)^{63}$, a singularidade da prorrogação de patentes prevista na exceção contida no art. 40 da LPI fica mais evidenciada quando está em cotejo com o art. 44 da mesma lei: “[o] art. 44, seguindo uma tendência das legislações de patente, garante a indenizabilidade das infrações incorridas em período anterior à concessão. Assim, ainda que haja retardo na concessão, o depositante poderá recobrar a lesão de seus interesses jurídicos. Já o art. 40 parágrafo único garante um prazo mínimo de vigência após a concessão. Mas não o faz, porém, cancelando a eficácia retroativa. Somam-se a retroação e a extensão. Com o prazo maior, os concorrentes - que pelas razões econômicas e de fato citadas acima não terão entrado no mercado - ficam proibidos de utilizarem a tecnologia revelada por tempo ainda maior dos que os vinte anos impostos pelo direito internacional".

Tal, nos leva a crer que o legislador proporcionou uma duplicidade de benefícios aos requerentes das patentes: primeiro com um monopólio de fato (Artigos 42 e 44 da LPI) e depois, se concedida a patente, com anos de monopólio extra (parágrafo único, Artigo 40, da LPI). Com efeito, a exceção contida no artigo 40, além de alimentar a demora sistemática do pedido de patentes, "afeta o acesso a medicamentos ao estender monopólios sobre medicamentos essenciais e a compensação não é justificável, porque o atraso no exame das patentes não prejudica o candidato, ao contrário; durante a longa espera, os produtos já estão no mercado e não enfrentam concorrência, pois qualquer rival

\footnotetext{
${ }^{62}$ Cf. CerqueIRA, João da Gama. Tratado da Propriedade Industrial, $3^{\mathrm{a}}$. Edição, anotado por Newton Silveira e Denis Borges Barbosa, Lumen Juris, 2010, vol. II, no. 159.

${ }^{63}$ BARBOSA, Denis Borges.op., cit., p. 74 ss.
} 
que arrisque entrar no mercado pode ser forçado a pagar danos retroativos se a patente for concedida" ${ }^{64 / 65}$.

E mais: a parte que pretende obter a aplicação de uma patente (geralmente uma multinacional de um país avançado) terá muito mais a ganhar do que aqueles que buscam contestar uma patente, por exemplo. STIGLiTZ et. al. (2017) ${ }^{66}$ afirmam que: "os processos judiciais para contestar a validade de patentes são dispendiosos e demorados. Se uma empresa tenta derrubar uma patente, o conhecimento incorporado à patente fica aberto para uso, inclusive por concorrentes e o custo em termos de dinheiro e esforço não são apropriados pelo desafiante da patente”. Nesse caso, cases paradigmáticos, como a rejeição da patente do medicamento Gleevec pelo Supremo Tribunal da Índia, em 2013, são uma exceção ${ }^{67}$.

Portanto, o Brasil é um dos poucos países a adotar a extensão do prazo de validade de patentes no direito interno ${ }^{68}$. Ainda, registre-se que a LPI já resguarda os interesses do

\footnotetext{
${ }^{64}$ [Nota do Original] Palavras de Pedro Villardi, coordenador do Grupo de Trabalho de Propriedade Intelectual (GTPI), que é baseado na Associação Brasileira Interdisciplinar de AIDS (Associação Brasiliera Interdisciplinar de Aids Observatorio Nacional de Politicas de Aids) (ABIA). Disponivel em: http://www.ip-watch.org/2018/05/18/patent-backlogs-fuel-efforts-extend-pharma-patent-terms-thailandbrazil-aidsactivists-say/ Acesso em 16 de março de 2018.

${ }^{65}$ STJ, $4^{\mathrm{a}}$ Turma, Min. Luis Felipe Salomão, Medida Cautelar Inominada de no 15222, DJ 20.02.2009: “[a] patente, da forma como foi concedida, não é um direito natimorto. Pois a nossa legislação conferiu efeitos retroativos à data do seu depósito, podendo o seu titular promover ações necessárias à defesa do seu direito". ${ }^{66}$ Cf. STIGLiTZ, Joseph E. et. al., op. cit. p. 42.

${ }^{67}$ Ver Novartis AG vS Union of India \& Others. Acórdão de 1 de abril de 2013. O Supremo Tribunal da Índia declarou que: "[u]m monopólio é concedido a um particular em troca da invenção sendo tornada pública para que, no final do prazo da patente, a invenção possa pertencer às pessoas em geral que possam ser beneficiadas por ela. Dizer que a cobertura de uma patente pode ir muito além da divulgação, portanto, parece negar a regra fundamental subjacente à concessão de patentes". Disponível em http://judis.nic.in/supremecourt/imgs1.aspx?filename=40212. Acesso em 21 de março de 2018.

${ }^{68}$ Após a assinatura do Acordo TRIPS, os EUA lançaram meios de objetivar que outros países também aderissem à extensão do prazo de validade de patentes em sua legislação interna (medidas TRIPs-plus), através de acordos de livre-comércio de onde se destaca um dos maiores acordos comerciais do mundo: 0 Acordo de Parceria Trans-pacífico, também referido como TPP (do inglês Trans-Pacific Partnership), que embora tenha como objetivo primário expandir a indústria nos países em desenvolvimento do Pacífico e estimular o comércio entre todos os países signatários, impôs, em seu esboço final, que cada país signatário fizesse "um ajuste necessário" para incluir a extensão do prazo de validade de patentes no ordenamento jurídico interno. O TPP alcançado finalmente em 2015 entre EUA e países com presença comercial significativa na região do pacífico (Chile, Nova Zelândia, Singapura, Brunei, Austrália, Peru, Vietnã, Malásia, México, Canadá e Japão), prevê a opção de extensão de patentes para os países signatários: "[o $] \mathrm{s}$ Estados Unidos procuraram incluir a opção de extensão de cinco anos no TPP, o que resultou em algum desacordo entre as outras partes". [...] "O esboço final do TPP exigia que cada signatário fizesse um "ajuste" disponível para termos de patentes farmacêuticas quando o produto farmacêutico estava sujeito a uma "redução não razoável" do prazo da patente devido ao processo de aprovação de comercialização" [...] "O TPP incorporou disposições do Acordo de Livre Comércio da América do Norte (NAFTA), que permitem que empresas farmacêuticas processem governos que rejeitaram seus pedidos de patentes cada vez mais perenes através de um mecanismo de resolução de disputas entre estados e investidores. Isso significa que o TPP poderia potencialmente incorporar a prática da evergreening farmacêutica no
} 
depositante de uma patente nos artigos 42 e 44 e que se a prorrogação do prazo de validade de patentes no parágrafo único do art. 40 se apresenta como "compensação" para o titular da patente, provavelmente estamos diante de um benefício bis in idem a favor da big farma em detrimento do interesse público no Brasil.

\section{JUDICIALIZAÇÃO DE MEDICAMENTOS E A EXTENSÃO DO PRAZO DE VALIDADE DE PATENTES}

O consumo de bens e serviços de saúde vem aumentando no Brasil desde 2010, em razão do crescimento e do envelhecimento populacional. De acordo com o IMS Health, estima-se que o mercado farmacêutico brasileiro mundial deverá alcançar em uma década, o $5^{\circ}$ lugar em faturamento mundial, ficando atrás somente de grandes potências como Estados Unidos, China, Japão e Alemanha ${ }^{69 / 70}$. Por sua vez, os gastos com medicamentos representam uma significativa parcela das despesas de saúde das famílias brasileiras (incluindo planos privados) e também das despesas governamentais, respectivamente: R $\$ 92,5$ bilhões, cerca de 1,5\% do PIB, e 10,9 bilhões, cerca de $0,2 \%$ do $\mathrm{PIB}^{71}$.

Subjacente a esse panorama, a indefinição do prazo de monopólio de exploração da propriedade industrial vem provocando lesões negativas a todo o sistema e a própria Constituição, especialmente ao direito à saúde, em razão da obstacularização à norma programática finalística do art. 196 da CFB, bem como à ordem econômica constitucional: a livre concorrência art. 170, IV, da CFB e defesa do consumidor arts. $5^{\circ}$,

\footnotetext{
comércio farmacêutico internacional. Isso permitiria que detentores de patentes farmacêuticas solicitassem novas patentes para pequenas alterações em seus produtos existentes, ampliando assim o monopólio das patentes e retardando ainda mais a introdução de genéricos no mercado. O resultado cumulativo dessas mudanças na lei internacional de patentes também pode comprometer um componente crucial do Acordo TRIPS chamada Declaração de Doha, que garantiu nações acesso a medicamentos essenciais". Para maiores desenvolvimentos, cf. STIMAC, Alexander, The Trans-Pacific Partnership: The Death-Knell of Generic Pharmaceuticals? 49 Vand. J. Transnat'l L. 853 (University Law School, Vanderbilt Journal of Transnational Law), 2016, p. 6 ss.

${ }^{69}$ INTERFARMA - Perspectivas do Mercado Farmacêutico para 2018, 05/01/2018 Disponível em https://www.interfarma.org.br/noticias/1494 Acesso em 06 de fevereiro de 2018.

${ }_{70}$ Ainda, acresça-se a essa panorama que o Brasil é um dos países que mais arrecada impostos sobre medicamentos ou seja: o consumidor financia seu tratamento terapêutico, através de medicamentos, e ainda paga um dos maiores tributos do mundos. Para maiores desenvolvimentos, ver: INTERFARMA Associação da Industria Farmacêutica de Pesquisa - Tributos e Medicamentos. (2012) https://www.interfarma.org.br/public/files/biblioteca/17-Livro\%20Tributos\%20e\%20Medicamentos\%20\%20site.pdf Acesso em 03 de abril de 2018.

${ }^{71}$ IBGE - Instituto Brasileiro de Geografia e Estatística. Conta-satélite de saúde: Brasil, 2010-2015. Rio de Janeiro: IBGE, 2018.
} 
XXXII, e 170, V, da $\mathrm{CFB}^{72}$. Isso ocorre, porque aos consumidores e aos demais interessados na exploração da patente farmacêutica, que não podem prever e programarse para iniciar a exploração da patente com a entrada de genéricos no mercado, a pendência prolongada, dificulta o acesso a medicamentos pela população, reduz a variedade de produtos e inibe a concorrência ${ }^{73}$. Portanto, o texto constitucional autoriza a intervenção estatal da economia, por meio de regulamentação e regulação de setores econômicos, desde que o exercício de tal prerrogativa esteja ajustado aos princípios e fundamentos da ordem econômica constitucional ${ }^{74}$.

Um estudo elaborado em 2013 pelo Centro de Estudos e Debates Estratégicos da Câmara dos Deputados, intitulado A revisão da Lei de Patentes: inovação em prol da competitividade nacional, concluiu que: "[n]o caso dos produtos farmacêuticos, por exemplo, a concessão de patente dificulta a efetivação das políticas públicas na área da saúde, além de restringir o acesso a tratamento adequado para grande parte da população, em razão dos altos preços cobrados pelo detentor de patentes ${ }^{75}$ ". E a "grande massa" ainda é dependente do sistema público de saúde, inclusive de forma indireta, obtendo medicamentos (geralmente de alto custo) distribuídos pelo governo por intermédio de demanda judicial ${ }^{76 .}$

\footnotetext{
72 “Art. 170. A ordem econômica, fundada na valorização do trabalho humano e na livre iniciativa, tem por fim assegurar a todos existência digna, conforme os ditames da justiça social, observados os seguintes princípios: [...] IV - livre concorrência; V - defesa do consumidor".

${ }^{73}$ Cf. UNITED KINGDOM. Intellectual Property Office. Patent backlogs and mutual recognition. Jan. 2010. Disponível em: http://bit.ly/ukipo002 ou https://www.gov.uk/government/publications/patentbacklogs-and-mutual-recognition; Acesso em: 12 maio 2018, p. ix.

74 “[...] De fato, o texto constitucional de 1988 é claro ao autorizar a intervenção estatal na economia, por meio da regulamentação e da regulação de setores econômicos. Entretanto, o exercício de tal prerrogativa deve se ajustar aos princípios e fundamentos da Ordem Econômica, nos termos do art. 170 da Constituição. Assim, a faculdade atribuída ao Estado de criar normas de intervenção estatal na economia (Direito Regulamentar Econômico, da lição de Bernard Chenot e Alberto Venâncio Filho, Droit public économique, Dictionnaire dês Sciences Économiques, 1958, pp. 420-423 e A intervenção do Estado no domínio econômico. O direito econômico no Brasil, 1968, respectivamente) não autoriza a violação ao princípio da livre iniciativa, fundamento da República (art. $1^{\circ}$ ) e da Ordem Econômica (art. 170, caput) [...]" Ver: STF. REXt 422941, Relator(a): Min. CARLOS VELLOSO, DJ 24-03-2006 - Trecho do voto do relator).

${ }^{75} \mathrm{O}$ estudo destina um tópico especial (tópico 4) para tratar da "não extensão do prazo de patentes" e ao final apresenta uma proposta legislativa (o PL 3.944/2012), de autoria da Deputada Jandira Feghali e outros, que propõe a supressão do parágrafo único do artigo 40 da Lei de Patentes. Disponível em: file:///C:/Users/Rafaella\%20Dias/Dropbox/tese/revisao lei patentes.pdf Acesso em 03 de janeiro de 2018. Atualmente, o PL 3.944/2012 ainda está em trâmite na Câmara dos Deputados, cujo ultimo andamento da em 09/03/2017. Disponível em http://www.camara.gov.br/proposicoesWeb/fichadetramitacao?idProposicao=545802 Acesso em 03 de janeiro de 2018.

${ }^{76}$ Cf. DÓRIA, R. Evolução do Padrão de Consumo das Famílias Brasileiras no Período 2003-2009 e Relações com a Distribuição de Renda. [Dissertação de Mestrado] Programa de Pós-Graduação em Economia, PPGE, do Instituto de Economia - UFRJ/Rio de Janeiro. 2013.
} 
Para atender as finalidades programáticas constitucionais (art. 196 da CFB) por meio das políticas públicas referentes à assistência terapêutica integral farmacêutica (art. $6^{\circ}$ da Lei 8.080/90) $)^{77}$, o governo brasileiro efetua a compra e distribuição de medicamentos pelo SUS com base no rol da Relação Nacional de Medicamentos Essenciais (Rename) ${ }^{78}$ e, portanto, paga os royalties ${ }^{79}$ ao titular da patente farmacêutica, enquanto perdurar a sua vigência. Um levantamento feito até 2016, elaborado pela UFRJ (Universidade Federal do Rio de Janeiro), a pedido da ABIA (Associação Brasileira Interdisciplinar de AIDS, Observatório Nacional de Políticas de AIDS), estimou em 2 bilhões de Reais adicionais o impacto causado ao Ministério da Saúde em compras centralizadas regulares de nove medicamentos essenciais (drogas usadas no tratamento de câncer, Aids e hepatite C) por força de prorrogações da validade de patentes que chegaram a alcançar mais de dez anos ${ }^{80}$. A pesquisa teve por hipótese comparativa a existência de medicamentos genéricos, que com base na Resolução no 2/2004 ${ }^{81}$ da Câmara de Regulação do Mercado de Medicamentos da Anvisa, dispõe que o preço de fábrica dos genéricos não poderá ser superior a $65 \%$ do preço dos medicamentos de referência correspondentes. Ou seja, admite-se por pressuposto que esses medicamentos seriam pelo menos $35 \%$ mais baratos na presença de genéricos ${ }^{82}$.

\footnotetext{
77 Vide item 3.2.1 deste trabalho.

78 “"a] Rename é a lista que define os medicamentos que devem atender às necessidades de saúde prioritárias da população brasileira no Sistema Único de Saúde (SUS). A lista de 2017 conta com 869 itens, contra 842 da edição de 2014 [...] A organização da Rename segue orientação da Organização Mundial da Saúde (OMS) que estabelece o material como uma das estratégias para promover o acesso e uso seguro e racional de medicamentos." Ver: MINISTÉRIO DA SAÚDE - Fundo Nacional de Saúde - Ministério da Saúde publica nova lista medicamentos essenciais para o SUS. 28.08.2017. Disponível em: http://portalfns.saude.gov.br/ultimas-noticias/1727-ministerio-da-saude-publica-nova-lista-demedicamentos-essenciais-para-o-sus Acesso em 05 de março de 2018.

79 "Royalty é uma palavra de origem inglesa que se refere a uma importância cobrada pelo proprietário de uma patente de produto, processo de produção, marca, entre outros, ou pelo autor de uma obra, para permitir seu uso ou comercialização". Ver: SENADO FEDERAL - Senado Noticias: Royalties. Disponível em: https://www12.senado.leg.br/noticias/glossario-legislativo/royalties Acesso em 02 de outubro de 2018.

80 Paranhos J. Projeto ABIA: extensão de patentes e custos para o SUS. Disponível em: http://www.abifina.org.br/arquivos/download/parecer ie ufrj.pdf Acesso em Julho 2016.

${ }^{81}$ ANVISA. Câmara de Regulação do Mercado de Medicamentos. Resolução no 2, de 5 de março de 2004. Diário Oficial União $\quad 2004 . \quad$ Disponível $\quad$ em: http://portal.anvisa.gov.br/documents/374947/2932039/Resolu $\%$ C3\%A7\%C3\%A3o +n $\%$ C2\%BA $+2+$ de + 5+de+mar\%C3\%A7o+de+2004+(PDF).pdf/b6d68347-a134-4465-a2f1-e5ed0cabc747 Acesso em 06 de maio de 2017.

82 A título de exemplo, é o que ocorre com uma patente associada ao medicamento Fosamprenavir (PI9912156). A mesma foi depositada no INPI em 1999 e concedida em 2016 ou seja, após dezessete anos de processamento. Em tese, teria mais 03 anos até sua patente expirar em 2019, à luz do Acordo TRIPS e do caput 40 da LPI. Graças à prorrogação contida na exceção do parágrafo único do Artigo 40, a patente da droga ganhará mais sete anos de validade, findando em 2023 sua extensão, para completar os dez anos de vigência previstos depois da concessão. Um estudo entabulado em 2017 estimou que os gastos com a aquisição desse medicamento demonstrou um valor médio anual de compras governamentais entre 20112014 de R\$ 40.033.800,00 e que, caso o mesmo tivesse sido fabricado por indústria genérica, o gasto
} 
O mesmo estudo ainda comprovou que sete medicamentos sob a égide da dilatação legal e adquiridos por determinação de ordem judicial, entre os anos de 2013 e 2015 (na modalidade de compra por dispensa de licitação em razão de interesse público ${ }^{83}$ ) totalizaram o montante vultoso de $\mathrm{R} \$ 6.802 .191,96$ a mais para o governo brasileiro. Isso ocorre, porque há muitos medicamentos que não são concedidos pelo SUS, ainda que considerados de imensa "essencialidade" para a saúde pública, como é o caso do medicamento Avastin (bevacizumabe).

\subsection{Case Study: medicamento Avastin}

O Avastin é um medicamento oncológico, reinvidicado em quatro pedidos de patente no Brasil (o PI9809388, o PI9809387 e suas divisões PI9816306 e PI9816350, todos da empresa Genentech (representada pela Roche no Brasil), depositados no INPI em 03/04/1998. O primeiro relatório do exame técnico para o pedido PI9809387 foi emitido somente em 22/04/2009, passados já 11 anos do depósito do pedido da patente. As patentes deveriam ser válidas até 2018, porém, após 20 anos do depósito dos pedidos no Brasil, o exame ainda está pendente, de modo que, quando concedidos, gozarão de um prazo de validade de 10 anos contados a partir de sua concessão (de acordo com o parágrafo único do artigo 40 da Lei de patentes, passando a vigorar até 2023. Em alguns países, esses pedidos já foram avaliados e concedidos, tais como Canadá, Estados Unidos, Japão, além de vários países da Europa. Em outros, as patentes para esse mesmo medicamento irão expirar entre os anos 2018 e 2019. Ressalte-se que o Avastin já possuía uma patente concedida no Brasil, a patente pipeline ${ }^{84}$ PP1101137, depositada em 1992, cuja validade findou em 2011.

governamental anual no mesmo período teria sido R $\$ 26.021 .970,00$. A conclusão obtida é que a prorrogação para o medicamento Fosamprenavir provocará um custo "adicional" de pelo menos R\$ 99.695.130,16 aos cofres públicos brasileiro. Ver JANNUZZI AHL, VASCONCELlOS AG. Quanto custa o atraso na concessão de patentes de medicamentos para a saúde no Brasil? Cad. Saúde Pública 2017; 33(8):e00206516, doi: 10.1590/0102-311X00206516, 2017, p. 3.

83 É reservada à Administração a discricionariedade para decidir, em face das circunstâncias do caso concreto, se dispensa ou não o certame. Até mesmo em presença da hipótese em que a dispensa é autorizada, a Administração Pública pode preferir proceder à licitação, se tal atender superiormente ao interesse público. Para maiores desenvolvimentos, ver: JunIOR, Jessé Torres Pereira. Comentários à Lei de Licitações e contratações da Administração Pública, São Paulo: Renovar, 2007. p. 290.

${ }^{84} \mathrm{As}$ patentes de medicamentos, alimentos e outros produtos concedidas por outros países foram revalidadas no Brasil, não havendo aferição dos requisitos técnicos e necessários à geração do direito de patente conforme deveria ser verificado pelo INPI, sendo observados os termos do pais estrangeiro. A novidade 
Inequivocamente, a perenização do monopólio de patentes com a mesma importância do medicamento Avastin é um grande desafio para a saúde brasileira, pois tarda a entrada de genéricos no mercado e impede que seja efetivado o interesse social com vistas à garantia à saúde para a maioria dos pacientes com câncer (tais como câncer colorretal, câncer de pulmão, câncer de mama e câncer de células renais). Ainda, ao mesmo tempo que o medicamento possui imensa importância para vários tratamentos oncológicos, possui também um custo elevadíssimo praticado ao alvitre da empresa dententora do monopólio que até os dias atuais não enfrenta concorrência no Brasil, chegando a custar até $\mathrm{R} \$ 6.484,23$ reais, o valor de uma ampola injetável de 400mg do Avastin - Roche $e^{85}$.

Considerando que a patente ainda não foi concedida pelo $\operatorname{INPI}^{86}$ e que até o momento o medicamento de altíssimo custo não é distribuído pelo SUS, a acessibilidade e variedade do mesmo se encontram reduzidas ao consumidor brasileiro. Tomando por base o estudo que trilhamos no capítulo anterior sobre judicialização da saúde no Brasil, pode-se considerar que o medicamento Avastin está entre os vários medicamentos pleiteados à justiça sob a forma de compelir o governo a concede-lo gratuitamente, à luz de fundamentos constitucionais, tais quais o direito à vida, à saúde e a dignidade da pessoa humana.

\footnotetext{
absoluta é o critério adotado pelo Brasil no que diz respeito às patentes, assim, o requisito da novidade não estaria sendo efetivamente cumprido, tendo em vista a publicidade existente. Com efeito, mais de mil remédios receberam em 1997 patentes pipeline com base nos artigos 230 e 231 da Lei de patentes brasileira. Economistas calcularam que, só para o medicamento Imatinib, o Estado brasileiro gastou 18 vezes mais do que se fosse adquirir o equivalente genérico. Já para o remédio Atorvastina o gasto foi 11 vezes maior. Assim sendo, nos anos da litispendência infrutífera da ADIn 4.234 de 2009, centenas de milhões de reais saíram dos cofres. públicos em virtude de uma lei cuja constitucionalidade foi contestada com base em sólidos argumentos, porém, perdeu o objeto já que as patentes adquiridas em 1997 já expiraram ou estão prestes a expirar, por força do prazo vintenário. Para maiores desenvolvimentos sobre a interpretação das patentes à luz dos princípios da Constituição Federal Brasileira de 1988, encontra-se o memorial de amicus curiae, elaborado pela FGV Direito Rio de Janeiro: Disponível em https://direitorio.fgv.br/sites/direitorio.fgv.br/files/u100/amicus_adi_5529_abia_assinado.pdf Acesso em 25 de janeiro de 2018. A tese da constitucionalidade dos artigos 230 e 231 é defendida em: CANOTILHO, J.G et. al. (2008). Dados e projeções financeiras em: http://www2.camara.leg.br/acamara/estruturaadm/altosestudos/seminarios/seminario-patentes-futuro-daindustria-nacional-de-farmacos/ReleasefinalSeminrio.pdf;\%20http. Ver também http://www.estadao.com.br/noticias/geral,lei-de-patentes-fez-pais-gastar-r-123-milhoes-a-mais com-4medicamentos-imp-,682272.

${ }^{85}$ Segundo a base de dados K@iros (Disponível em: www.brasil.kairosweb.com, acessado em 02 de junho de 2018) o preço de uma ampola do Avastin ${ }^{\circledR}$ (Roche) injetável $400 \mathrm{mg}$ custa entre: $\mathrm{R} \$ 5.894,76$ e 6.484,23. ${ }^{86} \mathrm{O}$ status legal dos pedidos de patentes no Brasil é verificado no INPI http://www.inpi.gov.br/pedidosem-etapas/faca-busca. Verificação do medicamento Bevacizumabe disponível https://gru.inpi.gov.br/pePI/servlet/PatenteServletController Acesso em 16 de maio de 2018.
} 


\title{
Em recentíssima decisão, o Tribunal Regional Federal - 4a Região manteve em grau
} de recurso a "tutela de urgência ${ }^{87 "}$ concedida pelo juízo a quo, determinando que a União, o Estado e o Municipio (através da responsabilidade solidária) ${ }^{88}$ fornecessem à parte requerente o medicamento Avastin (Bevacizumabe) por tempo indeterminado. Entre os fundamentos arrogados, o Relator entendeu que o STF está firmando jurisprudência no sentido de que há legitimidade constitucional para o controle e intervenção nas políticas públicas nos casos de abusividade e omissão governamental para fazer cumprir o direito à saúde. Transcreva-se, por oportuno, trecho do aresto:

\begin{abstract}
Legitimado está o Judiciário a intervir nas políticas públicas determinando que se cumpra a $\mathrm{CF} / 88$, notadamente o seu art. $196 \mathrm{da} \mathrm{CF} / 88$, preservando sua força normativa não podendo o Estado se furtar à sua obrigação sob alegações vazias e não comprovadas de ausência de recursos para a efetivação dos direitos sociais (" reserva do possível "), tendo em vista a necessidade de se garantir a todos o mínimo existencial, necessário a se viver com dignidade. Em que pese o fornecimento de medicamentos, em alguns casos, exija um alto custo, isso, per si, não pode ser empecilho para o seu fornecimento, como já decidido pelo Min. Gilmar Mendes, na STA n ${ }^{\circ} 175 \mathrm{AgR} / \mathrm{CE}$, nos seguintes termos:" o alto custo de um tratamento ou de um medicamento que tem registro na ANVISA não seria suficiente para impedir o seu fornecimento pelo poder público ". Deve-se ter sempre em vista que a vida protegida pela $\mathrm{CF} / 88$ não é qualquer tipo de sobrevivência, mas sim a vida digna, aquela na qual existe efetivamente um cidadão que possui direitos e deveres que devem ser garantidos e respeitados. Dessa forma, não é qualquer tratamento que deve ser custeado pelo Poder Público, mas sim aquele mais adequado e eficaz, capaz de ofertar ao enfermo maior dignidade e menor sofrimento, mesmo que seja de alto custo ${ }^{89}$.
\end{abstract}

\footnotetext{
${ }^{87}$ A tutela de urgência é prevista no Código de Processo Civil brasileiro e considerada satisfativa para evitar um grave dano, conferindo ao autor provisoriamente a garantia imediata das vantagens de direito material para as quais se busca a tutela definitiva. No caso concreto dos medicamentos, a tutela de urgência visa evitar o grave dano da piora do paciente que sem a obtenção a tempo do medicamento pode chegar, inclusive, à morte, caso tenha que aguardar o deslinde do processo. "A antecipação é dos efeitos práticos que seriam gerados com a concessão definitiva da tutela pretendida elo autor e não da tutela jurisdicional em si. Portanto, não se antecipa a tutela constitutiva ou declaratória da mesma forma não se antecipa a tutela condenatória, mas sim os efeitos que essas tutelas geram no plano dos fatos". Para maiores desenvolvimentos, ver: Neves, Daniel Amorim Assumpção. Manual de Direito Civil - volume único. 8ed. - Salvador: Ed. JusPodivm, 2016, p. 439.

${ }^{88}$ De acordo com precedentes jurisprudenciais do STJ: “[é] solidária a responsabilidade pela efetivação do direito à saúde (art. 23, inciso II, da CF), o que implica não apenas na elaboração de políticas públicas e em uma consistente programação orçamentária para tal área, como também em uma atuação integrada entre tais entes, que não se encerra com o mero repasse de verbas". Ver STJ - REsp 1657951 - Ministro MAURO CAMPBELL MARQUES - DJ 03/04/2017.

${ }^{89}$ Ver TRF-4 ${ }^{\mathrm{a}}$ REGIÃO: AG 50710072220174040000 5071007-22.2017.4.04.0000, Relator SÉRGIO RENATO TEJADA GARCIA, 12.01.2018. Disponível em: https://trf4.jusbrasil.com.br/jurisprudencia/539165344/agravo-de-instrumento-ag-507100722201740400005071007-2220174040000?ref=topic feed Acesso em 13 de março de 2018.
} 
A decisão supra faz parte do avolumado de ações judiciais no Brasil no que toca o requerimento por via judicial de medicamentos, que na sua maioria, são de alto custo e não constam no rol do Rename, logo, não são distribuídos pelo SUS ${ }^{90}$. A judicialização da saúde para o acesso a medicamentos "camufla" o sucesso no domínio da proteção à saúde, haja vista que a destinação de verbas para cada vencedor dessas ações representa um peso considerável aos cofres públicos e consequentemente a toda a sociedade civil. Nesse sentido, alguns precedentes jurisprudenciais são coerentes ao admitir que: "[n]ão é ônus do Judiciário administrar o SUS [...] os recursos do SUS são, notoriamente, escassos. Deferir-se, sem qualquer planejamento, benefícios para poucos, ainda que necessários, podem causar danos para muitos, consagrando-se, sem dúvida, injustiça. Sequer pode-se considerar o Judiciário como uma via que possibilite que um paciente possa burlar o fornecimento administrativo de medicamentos, garantindo seu tratamento sem que se leve em consideração a existência de outros na mesma ou em piores circunstância ${ }^{91}$."

Portanto, a dilatação do prazo de validade de patentes além de macular a livre concorrência, reduz as possibilidades do consumidor adquirir o medicamento por conta própria. Com efeito, vem tornando-se contumaz para uma parcela desses consumidores (na sua maioria pessoas com recursos) provocar o judiciário para a obtenção "indireta" de medicamentos pelo governo, na sua maioria, de alto custo. E embora esses grupos possam lograr êxito no caso concreto, a sociedade como o todo é quem suporta as consequências deletérias causadas pela extensão legal de patentes no ordenamento

\footnotetext{
${ }^{90} \mathrm{O}$ fornecimento de medicamentos sem que contenha na listagem do SUS faz parte dos Recusos Repetitivos do STJ. Recurso repetitivo, portanto, é aquele que representa um grupo de recursos especiais que tenham teses idênticas, ou seja, que possuam fundamento em idêntica questão de direito". Ver http://www.sti.jus.br/sites/STJ/default/pt BR/Processos/Repetitivos-e-IAC/Saiba-mais/Sobre-Recursos

Repetitivos Acesso em 02 de abril de 2018. "A Primeira Seção do Superior Tribunal de Justiça concluiu o julgamento de recurso repetitivo (REsp 1.657.156), relatado pelo ministro Benedito Gonçalves, que fixa requisitos para que o Poder Judiciário determine o fornecimento de remédios fora da lista do SUS. Os critérios estabelecidos só serão exigidos nos processos judiciais que forem distribuídos a partir desta decisão, sendo eles: 1 - Comprovação, por meio de laudo médico fundamentado e circunstanciado expedido por médico que assiste o paciente, da imprescindibilidade ou necessidade do medicamento, assim como da ineficácia, para o tratamento da moléstia, dos fármacos fornecidos pelo SUS; 2 Incapacidade financeira do paciente de arcar com o custo do medicamento prescrito; e 3 - Existência de registro do medicamento na Agência Nacional de Vigilância Sanitária (Anvisa)". Cf. REsp 1682973 / RJ RECURSO ESPECIAL 2017/0167357-7, Ministro O G FERNANDES (1139), T2 - SEGUNDA TURMA, DJe 11/06/2018.

${ }^{91}$ Ver TRF4 - Apelação $\mathrm{n}^{\circ}$ 5000879-84.2011.404.0000, Relatora Marga Inge Barth Tessler - D.E. 10/04/2011. Disponível em: https://trf-4.jusbrasil.com.br/jurisprudencia/561298920/apelacao-remessanecessaria-apl-50073239420164047005-pr-5007323-9420164047005/inteiro-teor-561298927 Acesso em 05 de abril de 2017.
} 
jurídico brasileiro, pois questões como essas, no entendimento de STIGLITZ (2014) ${ }^{92}$ : "[c]ostumam envolver um verdadeiro desperdício de recursos, o qual baixa a produtividade e o bem-estar do país. Distorcem a alocação de recursos e tornam a economia mais fraca".

\section{CONCLUSÃO}

Não raras são as divergências existentes no modus de realização do direito à saúde pelos Estados. Nesse particular, a saúde no Brasil vem enfrentando questões delicadas, sobretudo no que diz respeito o acesso a medicamentos. Embora haja um lastro de políticas públicas no desiderato das normas programáticas finalísticas contidas na constituição federal brasileira de 1988, há algumas incoerências normativas e políticas encontradas no plano infraconstitucional que acabam por fragilizar a concretização do direito à saúde ao acesso a medicamentos, a médio e longo prazo.

A esse despeito, à revelia da disponibilidade de recursos materiais e humanos sob a averiguação prévia orçamentária, vimos que o poder judiciário de há muito no Brasil vem arrogando uma legitimidade constitucional para o controle e intervenção nas políticas públicas nos casos em que considera o governo omisso à concretização da saúde para o fornecimento de medicamentos não distribuídos por meio do SUS. Desse modo, o fenômeno da judicialização de medicamentos, cada vez mais fortalecido na interpretação da fundamentalidade da saúde por efeito imediato, se opera em números já contundentes de ações judiciais no país, camuflando um êxito no domínio da proteção à saúde.

Contudo, não é hostil pensar que essa circunstância é sem dúvida injusta para a sociedade, pois o fenômeno da judicialização se caracteriza como um paliativo à inacessibilidade de medicamentos por conceder o seu fornecimento apenas a uma determinada parcela da população que, na sua grande maioria, possui recursos suficientes para manejar a pretensão através de escritórios de advocacia especializados na questão em causa. De revés, a coesão social é afetada na medida em que políticas públicas para o próprio setor, de caráter universal, são desprivilegiadas em razão do desvio forçado de verbas não negligenciáveis para conter a "sangria” dessas demandas judiciais.

\footnotetext{
${ }^{92}$ Cf. STiglitZ, Joseph, op., cit., p. 101 e 165.
} 
E então, com a impossibilidade da inserção de alguns medicamentos genéricos no mercado, os efeitos da famigerada prorrogação no prazo de validade de patentes para o Brasil já são em números um deletério impacto a seus cofres públicos. Para compras centralizadas regulares de nove medicamentos de referência e essenciais, um estudo revelou que até 2016, o Ministério da Saúde desembolsou 2 bilhões de reais a mais. Para sete medicamentos adquiridos por determinação de ordem judicial, o valor superou a cifra de 6 bilhões de reais somente entre os anos de 2013 e 2015. Esses valores estão refletidos na quantidade absurda de processos judiciais em trâmite na área da saúde até o ano de 2017: 1.346.931, onde o pedido de fornecimento de medicamento pelo SUS se destaca como o campeão de litígio, com 312.147 de ações ainda em curso.

Não há como negar que a extensão do prazo de validade de patentes é uma das principais causas da judicialização de medicamentos, especialmente porque a grande maioria, possue custo elevado. Os desvios forçados dessas verbas e de compras regulares, pelo governo, de medicamentos que já deveriam estar sob o domínio público são, de revés, nocivos à própria concretização da saúde no Brasil.

E comprova essa circunstância na hipótese dos reiterados cortes orçamentários pelo governo à Fundação Oswaldo Cruz (FIOCRUZ): um dos maiores centros de pesquisa à saúde e desenvolvimento social em medicamentos de referência com subsídios do governo brasileiro. (FIOCRUZ), que recebe subsídios do governo brasileiro para promover a saúde e desenvolvimento social, com projetos de P\&D em medicamentos de referência, destacando-se como um dos principais centros de pesquisas de doenças tropicais no Brasil, anunciou muito recentemente um corte orçamentário de R\$ 5,2 milhões em 2018 e o cancelamento de R 135 milhões no Programa Fortalecimento do Sistema Único de Saúde (SUS), este último, através da Medida Provisória 839. Os cortes já são comuns há alguns anos para a Fundação, o que é deletério para o direito à saúde, através do enfraquecimento de incentivo às políticas públicas, bem como ao desenvolvimento P\&D de medicamentos pioneiros no país ${ }^{93}$.

Desse modo, entendemos que o impacto econômico e social causados pela leniência da administração, alimentada pelo uso arbitrário da extensão de patentes no direito brasileiro, é uma sangria que resvala negativamente para o próprio setor da saúde, quando vimos, a exemplo do que está a ocorrer com a FIOCRUZ, que a sociedade civil brasileira

\footnotetext{
${ }^{93}$ BRASIL. Fundação Oswaldo Cruz - FIOCRUZ. Fiocruz avalia consequências de corte orçamentário. 05.06.2018. Disponível em https://portal.fiocruz.br/noticia/fiocruz-avalia-consequencias-de-corteorcamentario Acesso em 15 de junho de 2018.
} 
A EXTENSÃO DO PRAZO DE VALIDADE DE PATENTES COMO UMA DAS CAUSAS DA

JUDICIALIZAÇÃO DE MEDICAMENTOS NO BRASIL

E-ISSN 2316-8080

quem arca com o ônus da ineficiência administrativa e legiferante causados pela extensão do prazo de validade de patentes farmacêuticas.

E por não poder custear ela mesma a compra de determinados medicamentos, que ainda estão sob o manto do monopólio extensivo de patentes, recorre ao judiciário corriqueiramente para obtenção indireta dos mesmos pelo governo, sendo, inequivocamente, uma das causas da judicialização de medicamentos no Brasil.

\section{REFERÊNCIAS}

AleXY, Robert. Teoria dos direitos fundamentais. Trad. Virgílio Afonso da Silva. São Paulo: Malheiros, 2008

Barbosa, Denis Borges. A propriedade intelectual no século XXI: estudos de Direito.

Rio de Janeiro: Lumen Juris, 2009

BARROS, Carla Eugenia Caldas. Manual de Direito da Propriedade Intelectual, Evocati: Aracaju, 2007.

BARROS, Carla Eugenia Caldas. Aperfeiçoamento e Dependência em Patentes, Lumen Juris: Rio de Janeiro, 2004

Baker, Dean, Jeyadev Arjun, Stiglitz, Joseph E. (2017) Inovação, Propriedade Intelectual e Desenvolvimento: Um conjunto melhor de abordagens para o século 21. (Traduzido por James Tibúrcio). accessibsa, p. 10. Disponível em http://accessibsa.org/arguments-port/ Acesso em 03 de janeiro de 2018

Basso, Maristela. Comentário ao art. 5 XXIX. in: CAnotilho, J.J. Gomes; Mendes, Gilmar F.; SARLeT, Ingo W.; StReCK, Lenio L.(coords.). Comentários à Constituição do Brasil. São Paulo: Saraiva/Almedina, 2013

BILChITZ, David - Poverty and Fundamental Rights, New York, 2007

BrunNer, Georg. Die Problematik der sozialen Grundrechte. In: Rechtund Staar Nr. 404-405, J. C. B. Mohr (Paul Siebeck), Tubingen, 1971

CAlabresi, Guido e Bobitti, Philiph - Tragic Choices, W. W. Norton \& Company, Nova York, 1978 
Canotilho, Gomes J.J, Para uma Revisão da Dogmática da Jusfundamentalidade, in "Estudos em Homenagem a Antonio Barbosa de Melo", Coimbra, Almedina, 2013

CerqueIRA, João da Gama. Tratado da Propriedade Industrial, $3^{\text {a }}$. Edição, anotado por Newton Silveira e Denis Borges Barbosa, Lumen Juris, 2010, vol. II, no. 159

DÓRIA, R. Evolução do Padrão de Consumo das Famílias Brasileiras no Período 20032009 e Relações com a Distribuição de Renda. [Dissertação de Mestrado] Programa de Pós-Graduação em Economia, PPGE, do Instituto de Economia - UFRJ/Rio de Janeiro. 2013

Gonçalves, Luís Manuel Couto, Manual de Direito Industrial: Patentes; Desenhos ou Modelos; Marcas; Concorrência Desleal, $2^{\mathrm{a}}$ ed., Coimbra, Almedina, 2008

GonÇALVEs, Rafaella Dias, PIDCC, Aracaju/Se, Ano VII, Volume 12 nº 03, p.046 a 081 Out $/ 2018$

HABERMAS, Jürgen. Direito e Democracia - entre facticidade e validade. vol. I. Rio de Janeiro: Tempo Brasileiro, 2003

KING, Jeff - Juding Social Rights, Cambridge University Press, 2012

Krell, Andreas. Controle judicial dos serviços públicos básicos na base dos direitos fundamentais sociais. In: SARLET, Ingo Wolfgang (Org.). A Constituição Concretizada - Construindo pontes para o público e o privado. Porto Alegre: Livraria do Advogado, 2000

JANNUZZI AHL, VASCONCELlOS AG. Quanto custa o atraso na concessão de patentes de medicamentos para a saúde no Brasil? Cad. Saúde Pública 2017; 33(8):e00206516, doi: 10.1590/0102-311X00206516, 2017

Junior, Jessé Torres Pereira. Comentários à Lei de Licitações e contratações da Administração Pública, São Paulo: Renovar, 2007

JúNIOR, Sílvio Sobral Garcez e MoreIRA, Jane de Jesus da Silveira: O Backlog de patentes no Brasil: o direito à razoável duração do procedimento administrativo. Revista Direito GV | São Paulo | v. 13 n. 1 | 171-203 | jan-abr 2017

LABRUNIE, Jacques. Direito de patentes: condições legais de obtenção e nulidades. Barueri, 2006

Marques, João Paulo Remédio (II), Medicamentos Versus Patentes - Estudos de Propriedade Industrial, $1^{\mathrm{a}}$ ed., Coimbra, Coimbra Editora 
A EXTENSÃO DO PRAZO DE VALIDADE DE PATENTES COMO UMA DAS CAUSAS DA

JUDICIALIZAÇÃO DE MEDICAMENTOS NO BRASIL

E-ISSN 2316-8080

Mendes, Gilmar Ferreira. A Doutrina Constitucional e o Controle de Constitucionalidade como Garantia da Cidadania - Necessidade de Desenvolvimento de Novas Técnicas de Decisão: Possibilidade da Declaração de Inconstitucionalidade sem a Pronuncia de Nulidade no Direito Brasileiro. In: Caderno de Direito Tributário e Finanças Públicas, nº. 3. 1993

Moraes, Alexandre de - Direito Constitucional, 33 a ed., São Paulo, Atlas, 2017

MoraIs, Carlos Blanco de Morais - Curso de Direito Constitucional, Teoria da Constituição em Tempo de Crise do Estado Social, Tomo II, Vol. 2, Coimbra, Coimbra Editora, 2011

NovaIs, Jorge Reis, Direitos Sociais - Teoria Jurídica dos Direitos Sociais Enquanto Direitos Fundamentais, Coimbra, Wolters Kluwe/Coimbra Editora, 2010

OLSEn, Ana Carolina Lopes. Direitos fundamentais sociais: efetividade frente a reserva do possível. Curitiba: Juruá, 2008

PAtol, J. Bras. Nossa capa: Alexander Fleming e a descoberta da penicilina, Med. Lab. vol.45 no.5 Rio de Janeiro Oct. 2009

SARlet, Ingo Wolgang e SAAVEDRA, Giovani Agostini - Judicialização, Reserva do Possível e Compliance na Área da Saúde -, R. Dir. Gar. Fund, Vitória, v. 18, n.1, 2017

Os Direitos Sociais como Direitos Fundamentais: contributo para um balanço aos vinte anos da Constituição Federal de 1988 - Revista do Instituto de Hermenêutica Jurídica. 20 Anos de Constitucionalismo Democrático - E Agora? Porto Alegre-Belo Horizonte, 2008.

Silva, José Afonso da. Comentário contextual à Constituição. 7. ed. São Paulo: Malheiros, 2010

Stiglitz, Joseph. O preço da desigualdade. (Traduzido por Dinis Pires; rev. Sandra Areias). - $1^{\text {a }}$ ed., reimp. - Lisboa: Bertrand, 2014

Stimac, Alexander, The Trans-Pacific Partnership: The Death-Knell of Generic Pharmaceuticals? 49 Vand. J. Transnat'l L. 853 (University Law School, Vanderbilt Journal of Transnational Law), 2016 